Discussion

Papers

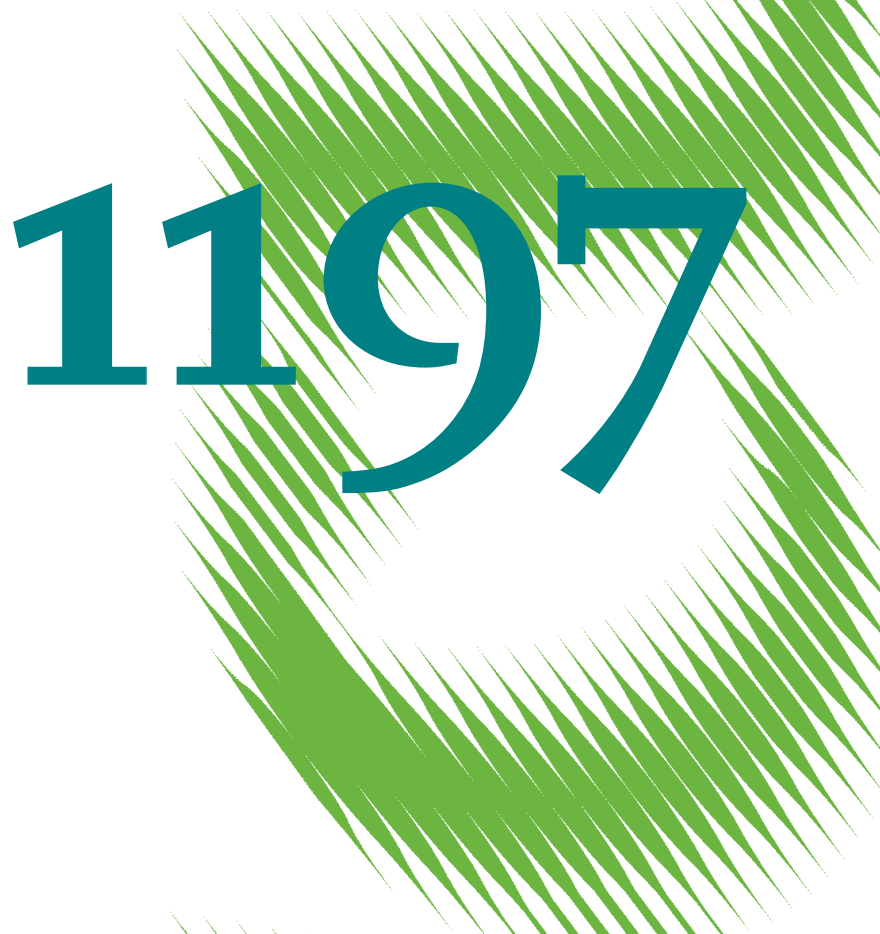

Movers or Stayers? Understanding the Drivers of IDP Camp Decongestion during Post-Conflict Recovery in Uganda 
Opinions expressed in this paper are those of the author(s) and do not necessarily reflect views of the institute.

IMPRESSUM

(C) DIW Berlin, 2012

DIW Berlin

German Institute for Economic Research

Mohrenstr. 58

10117 Berlin

Tel. $+49(30) 89789-0$

Fax +49 (30) $89789-200$

http://www.diw.de

ISSN print edition $1433-0210$

ISSN electronic edition 1619-4535

Papers can be downloaded free of charge from the DIW Berlin website:

http://www.diw.de/discussionpapers

Discussion Papers of DIW Berlin are indexed in RePEc and SSRN:

http://ideas.repec.org/s/diw/diwwpp.html

http://www.ssrn.com/link/DIW-Berlin-German-Inst-Econ-Res.html 


\title{
Movers or Stayers? Understanding the Drivers of IDP Camp Decongestion during Post-Conflict Recovery in Uganda ${ }^{1}$
}

\author{
Carlos Bozzoli*, Tilman Brück** and Tony Muhumuza**2
}

${ }^{*}$ German Institute for Economic Research (DIW Berlin), and Households in Conflict Network (HiCN)

**German Institute for Economic Research (DIW Berlin), Households in Conflict Network (HiCN) and Humboldt University of Berlin

\begin{abstract}
The paper explores factors that influence the household decision to leave internal displacement camps in the immediate aftermath of violent conflict. Our analysis is based on two sources of information: household survey data collected in northern Uganda for households that were displaced by the civil conflict, and geo-referenced data on armed conflict events, with which we construct our developed index of recent conflict exposure. We compare households that moved out of camps with those that remained in the camps after the region was declared safe from rebel incursions. The study covers the first few months of the end of conflict, when return was regarded as largely voluntary. We find that a history of conflict both at the place of residence, and at the expected place of return reduces the likelihood of return. Access to camp services overall encourages households to stay in camps, although the effect varies with the proportion of young household members. Results also show that a history of economic skills poses varying effects on return decisions. While experience in cultivation is associated with a high likelihood of moving out of the camp, households with members with recent experience in trading are less inclined to return. From a policy perspective, the results point to the need for recovery initiatives to ensure access to adequate infrastructures in return locations in order to fast-track reintegration.
\end{abstract}

Key words: Conflict, IDP, northern Uganda, returnees

JEL Classifications: D74, J60, R23

\footnotetext{
${ }^{1}$ We thank Adam Lederer, Urich Hendel, Yukako Karato, participants of the $15^{\text {th }}$ Annual Conference on Economics and Security, May, 2011, participants of the TAMEAC kick-off workshop, November, 2011, for comments on earlier versions. We also thank the Norwegian Fafo Institute for Labour and Social Research, and the Peace Research Institute Oslo (PRIO) for ganting us access to the data. Tony acknowledges financial support from The German Academic Exchange Service (DAAD).

${ }^{2}$ Corresponding author: email: tmuhumuza@diw.de
} 


\section{Introduction}

Little is known about why people return home despite decades of research on migration. Within the field of forced migration, there is a big gap between conflict-induced displacement and voluntary return after violent conflict. This subject is important because forced migration is one of the most daunting humanitarian challenges in the world today. By 2011, more than 42 million people worldwide were forced to leave their homes due to violent conflict. Of these, about 27.5 million were displaced within their own countries (IDMC, 2011). The African continent hosts almost half of the internally displaced persons (hereafter, IDPs), most of whom are victims of civil conflict (Crisp, 2010; Czaika and Kis-Katos, 2009; Ojeda, 2010).

Violent conflict affects IDPs in a number of ways. At their places of origin, conflict is often associated with severe destruction of property (Shemyakina, 2006), depletion of household assets (Bundervoet and Verwimp, 2005), disruption of labour markets and economic activities (Gonzalez and Lopez, 2007; Shemyakina, 2006) and severe loss of lives (Bundervoet and Verwimp, 2005; Verwimp, 2005). Households displaced into camps face deplorable living conditions. Camps are associated with poor health conditions which result in high rates of mortality and morbidity (Verwimp and van Bavel, 2005). There is also evidence that displaced households significantly reduce consumption and asset levels compared to households that do not move (Fiala, 2011). IDPs are often exposed to violence and lose their cultural and social identities, their livelihoods, and are subjected to a host of human rights violations (Ferris et al., 2011; USIP, 2011). These experiences could impact negatively on household behaviour long after the war has ended (Collier et al., 2003; Hoeffler, 2008).

After violent conflict subsides, one of the central issues discussed by governments and humanitarian agencies is how to facilitate the return of IDPs to their homes. During early periods of recovery, however, the prospects of households re-integrating into their original communities is limited. IDPs must decide whether to return to their communities or stay longer, or even permanently, in areas of displacement (IDMC, 2009), assuming that they are not forced to return. A number of factors may facilitate or inhibit such a voluntary return process, and manifest at the individual, household and community levels (Deininger et al., 2004; Pantuliano et al., 2007; Shewfelt, 2007). Understanding drivers of IDP return matters for post-conflict recovery interventions for a number of reasons. On one hand, factors that impede return have negative implications for recovery. On the other, factors that facilitate return provide an opportunity for a quick recovery. Understanding postwar movements is also important for planning service delivery. 
Most studies on IDPs focus on the drivers of conflict-induced displacement (see, for instance, Czaika and Kis-Katos, 2010; Ibáñez and Velez, 2007; Mesnard, 2009). While research on returning after conflict is relatively thin, most investigate intentions to return rather than whether the move out actually occurred or not. Notable among theres literatures is a study in Columbia by Deininger et al. (2004), that analyses the determinants of the desire by IDPs to return. Vinck and Pham (2009) addresse this question using data for IDPs in four districts of Northern Uganda. A common finding between these studies is that past war experiences, services and economic opportunities in return locations, as well as individual characteristics accounted for the differences in the desire to return.

Shewfelt (2007) provides a more appealing analysis of return after violent conflict by investigating actual decisions to return, using data from the Aceh province of Indonesia. Shewfelt's findings reveal a strong effect of security-related factors in shaping individual return decisions. Closely related to Shewfelt's work, this paper analyses the determinants of actual return, for a Ugandan sample. The difference here lies in four aspects. Our study covers a sample of 3900 households, more than twice as much as the Aceh sample, which is advantageous for detecting smaller effects. Unlike the data for Aceh, the Uganda survey allows for assessment of the pre-return IDP camp situation for households that moved, particualry with regard to facilities. In addition, we use a more dissagregated measure of exposure violent conflict, that we perceive to shape return decisions. Finally, we model the household rather than individual return decision.

This chapter contributes to two different threads in the literature, namely those on forced migration and on the economics of conflict. To these literatures, we make three contributions. First, building largely on migration literature, we study actual movement in a post- conflict setting. We account for conflict in this context, studying households forcefully dislocated during war. Second, we make the first attempt to capture household movements immediately after the end of mass violent conflict. Third, we apply a novel approach that we recently developed to measure exposure to violent conflict (see Bozzoli et al., 2011). Rather than counting the number of events in respective districts, this approach involves weighting individual conflict episodes based on how far they are from respective households. Such a measure accounts for the fact that households located at different points in the same district experience different degrees of exposure to violent conflict. Accounting for recent exposure to war is important, given that war shapes individual expectations and preferences (Bozzoli et al, 2011; Voors et al., 2010), human capital (Justino and Verwimp 2006), household welfare 
(Fiala, 2011; Justino, 2011), and the local economy ( Brück, 2004), all of which are vital for reintegration after conflict.

We find that a history of conflict, both at the place of residence and at the expected place of return, reduces the likelihood of leaving a camp. Access to camp services generally encourages households to stay in camps, although the effect varies with the proportion of different age groups in the household. Economic skills accumulated in the past (before the move out) have varied effects. While previously participating in cultivation and herding is associated with a high likelihood of leaving the camp, the reverse is true for involvement in trading.

From a policy perspective, these results underscore the importance of fast-tracking service delivery in return areas to facilitate reintegration. Providing an environment conducive to the proper functioning of markets could improve opportunities for the reinstatement of livelihood, and reduce costs of return. This could go hand-in-hand with measures aimed to ensure that households preserve relevant skills for recovery upon return. These could ba achieve, in part, if security concerns and their resultant effects on individual and household behaviour are addressed.

The remainder of this paper is structured as follows: The next section presents a review of related literature. Section 3 provides a background to conflict and displacement in northern Uganda. The data set is described in Section 4. The theoretical framework and empirical model are presented in Sections 5 and 6, respectively. Descriptive statistics and empirical results are provided in Sections 7 and 8, respectively. Section 9 discusses the results and concludes the study.

\section{Literature on migration and return}

Migration literature has a rich tradition of describing patterns of movement and their drivers. Economic theory postulates that migration is an investment decision that involves future costs and benefits. A utility maximizing agent makes rational decisions depending on the utility derived from alternative actions (stay, migrate) and will decide to migrate when the expected benefits of migrating exceed the costs in present value terms (Navratil and Doyle, 1977; Todaro, 1976). In this framework, individuals would, for instance migrate to an economy where wages are high, if the expected value of their lifetime income, net of costs, is higher than in their low-wage economy (Harris and Todaro, 1970;Todaro and Maruszko, 1987). In the event that the value of life time income becomes higher in their place of origin, 
than in their receiving communities, return would be an optimal decision. This could occur if the conditions in either of the locations changes, such that the wage differential favours return, or individual expectations about the receiving community were too high.

While neoclassical micro economic theory views migration as an individual decision driven by utility maximization, household migration theory posits that household welfare matters more than individual expected utility (Mincer, 1978; Stark and Bloom, 1985; Stark, 1993; Massey et al., 1993). In this context, the decision to migrate or return is a joint decision of a larger unit of related people because the cost and benefits of either action are often shared.

Return migration can also be explained in the framework of the segmented labor-market theory. This theory argues that labour opportunities in the receiving community may be reserved to individuals on certain grounds, for instance, residence status, gender and education (Bailey and Cooke, 1998). In such a case, migrants who may fail to find jobs, may choose to return home.

Networks in receving communities have also been regarded as vital for the integration and adjustment of migrants. The network theory contends that networks make it easier for migrants to secure housing, support in finding employment and other contacts. Absence of an active network system may result in return migration for those who cannot cope without them (Orrenius, 1999). Return migration can also be explained from the perspective of the life cycle theory. The theory views return as a process of individual advancement from one age to another, such that one returns after reaching a certain age (Borjas and Bratsberg, 1996). Life cycle migrants determine the length of stay in the host community. They often compare the benefits of higher savings and higher lifetime consumption, with the marginal utility cost of work in receiving communities. Their primary objective is to accumulate savings and return home to consume (Yang, 2007).

In another framework, individuals are regarded as deriving utility from comparing themselves to others in the same community (Stark, 1984; Stark and Yitzhaki, 1988). Individuals who regard themselves are poor would opt to migrate to other locations to better their lives. With time, they begin to compare their wellbeing with members of the receiving community, and choose to return if they expect to be relatively better-off in their home communities. 
In order to understand the mechanisms that underlie return migration, it is imperative to recognize that the circumstances under which individuals might migrate from their homes may be varied, and these could play a key role in informing their return decisions. For instance, while migration during violent conflict is forced, usually as a result of a deliberate strategy pursued by combatants, individuals that live under peaceful conditions largely move by choice. Thus, post-conflict returnees may face different mechanisms that influence return decisions, from those who migrated under normal security situations. However, for circumstances where return after conflict is voluntary, there is evidence that formally displaced individuals may exhibit rational behaviour that is comparable to those who left their homes by choice, although drivers of return could differ (Deininger et al., 2004).

Literature on refugee repatriation shows that displaced persons tend to possess control over the timing and context of their return, if return is voluntary (Koser, 1993). They often assess the conditions at home before deciding to return (Rogge and Akol (1989). These decisions may in part be influenced by their duration of stay in host communities. Long displacement spells may be associated with a high level of acculturation in host communities, thus discouraging return (Djuraskovic and Arthur, 2009; Badurdeen, 2010). In Tanzania, for instance, $80 \%$ of Burundian refugees who were displaced in 1972 opted for citizenship, while others resisted repatriation efforts (Hovil and Bueno, 2011). Return may also be influenced by the perception of the prevailing security situation in return communities. In Chad, a report by Oxfam (2010) indicated that IDPs were not willing to return as long as their security was not guaranteed. Similar findings were obtained among IDPs in Uganda (Brown, 2006) and Timor (ICG, 2008).

Closely related to security concerns, the experience of trauma during conflict may shape the return process. When displacement is caused by traumatic events, such as death of a household member, families are reluctant to leave receiving communities (Deininger et al., 2004). Research among IDPs in Indonesia reveals that those who lost relatives as a result of conflict were less likely to go back to their homes (Turnip 2003). Kalyvas (2006) notes that the nature of violence may vary widely at the local level such that communities may have different conflict experiences even when they share a common boundary. Such differences may influence the nature of the post-conflict setting. If displacement was a deliberate strategy to alter the ethnic, political, or demographic composition of a community, reintegration may be further delayed and complicated (Reilly and Risser, 2000). With evidence thus far, it is clear that the role of conflict experiences on individuals or households should not be 
underestimated during post-conflict recovery. Experiences of violence may be deeply rooted in affected parties to the extent that their decisions long after the conflict may in part be hinged on how much they were affected.

Displaced persons may also compare the economic survival possibilities between their current locations and their homes, which may affect the timing of return (Deininger et al. 2004; Koser, 1997). In Kossovo, for example, lack of employment prospects hindered the reintegration process, forcing young families to either stay longer or to out-migrate (Rabenhorst, 2003). In Uganda, existence of trading opportunities in IDP camps discouraged early reintegration (Bjorkhaug et al., 2007). Individuals may also prefer to prolong their stay when they expect the institutional conditions necessary for sustainable reintegration in return locations to be absent for a longer time (USIP, 2011; Vinck and Pham, 2009). For instance, households without children in school may find it is easier to return (Pantuliano et al., 2007), while other households may delay their return if it is expected to disrupt child schooling, especially if education facilities are non-existent in return areas (LEMU, 2006). Continued provision of relief services may also delay reintegration. This is most likely for vulnerable individuals and those who lose livelihoods to the extent that their survival may not be guaranteed on return (Knoeche, 2010). More households headed by males register higher return patterns than households managed by women (Bjorkhaug et al., 2007), but this is less likely if males were the main victims of conflict (Shewfelt, 2007).

From the above literature, is evident that most of the existing studies on return migration after violent conflict are qualitative. Due to data limitations, there is lack of quantitative work on actual return decision in during the immediate aftermath of violent conflict. Work by Shewfelt (2007) in Indonesia analysed this question using data that were collected between February and April 2007, about 18 months after the conflict that ended. This chapter uses data collected around the same time, but about 8 months after the region was declared peaceful. We therefore able to capture household movement soon after war. In addition using a larger sample, and being able to identify pre-return camp facilities for those who moved, we use a measure of conflict exposure which is more disaggregated at the village level, compared to the sub-district level for Indonesia. This measure may reflect household past exposure to conflict more precisely. 


\section{Conflict, displacement and the return process in Northern Uganda}

Violent conflict in northern Uganda began in 1986 when rebel forces opposed to the newly formed government took over power. Until 2002, the war was concentrated in the Gulu, Kitgum and Pader districts of the Acholi sub region. Attacks later spread to the Lango and Teso sub regions. Throughout the 1980s, the conflict remained largely military in nature. However, in the early 1990s, the Lord's Resistance Army (LRA) rebels began to focus on the local population and instill terror among villages by ambushing, looting and killing civilians. The rebel movement was also known for abducting young people on a large-scale to boost their forces (Blattman, 2010). The UNICEF (2006) report indicates that more than one in three young men and one in six young women had at least once been abducted.

In 1996, the government began a policy of moving civilians forcefully from their homes to "protected villages". These villages were, in essence, camps for the internally displaced population. Systematic displacement increased in 2002, during military operations against the LRA in southern Sudan ("Operation Iron Fist"). The war resulted in the displacement of 1.8 million people, almost $90 \%$ of the population in the region (IDMC, 2008). The government argued that relocating households into IDP camps was necessary in order to protect communities from LRA attacks. By 2006, there were a total of 220 registered camps in the region. The majority of the displaced persons endured deplorable conditions in camps. They were denied freedom of movement by the military, lacked access to sufficient social infrastructure and had no access to adequate food and income-generating activities. Living in overcrowded settlements resulted in poor health conditions, with high incidence of diseases and fatalities (Bozzoli and Brück, 2010; Jacobsen et al., 2006).

The difference between the conflict in northern Uganda and other research conflicts is that the displacement was not idiosyncratic. Displacement, wherever it was effected applied to all households irrespective of social and economic status. There was therefore no sample selection bias in displacement.

Between 2006 and 2007, following a cease-fire agreement (August 2006), and a series of peace negotiations between government and rebel forces, the security situation improved. From the ceasefire onwards, IDPs were allowed to return home. Camp phase-out guidelines were drawn to aid the return process. These guidelines stipulated that the right to freedom of movement should be respected (GoU, 2008). At least by 2007, households in IDP camps were 
still free to make decisions whether to return or stay longer (Oxfam, 2008; USAID, 2007) ${ }^{3}$. With joint effort from government and relief agencies, IDPs were provided with information via radio broadcasts, regarding the conditions in the areas of their origin in order to allow them to make informed decisions about voluntary return (USAID, 2008). As a result of the improved security situation, a number of IDPs were encouraged to move closer or return to areas of origin. Although the large-scale movement of IDPs from camps did not gain momentum until 2008 (IDMC, 2010a), by May 2007, more than 850,000 displaced persons had voluntary left the camps (USAID, 2007).

The return process was fast in the Lango sub region, such that by the end of 2007, almost all households had moved out of camps (Oxfam, 2008). This was attributed to the late displacement of households in this region, and faster return to normalcy (Bjorkhaug et al., 2007). By November 2010, there were a total of 13 camps left in Acholi sub region. More than $90 \%$ of the displaced people had returned home, while only 182,000 people were still in camps or transit sites (IDMC, 2010a).

(Figure 1 about here)

For households that were still in camps, the living conditions improved and previous restrictions of movement were lifted. IDMC (2010b) highlighted four categories of IDP residents who could remain in camps. These included the "extremely vulnerable individuals" and people with special needs, people who were unable to return due to land disputes, individuals who wanted to take advantage of the IDP policy of "freedom of movement" to return when they wished, young people who were left behind by their families to benefit from services provided in camps such as education and health care, and those who did not intend to return due to the existence of better product markets in camps.

\section{Data sources}

\subsection{Northern Uganda Livelihood Survey-NULS (2007)}

We use data from the Northern Uganda Livelihood Survey-NULS (2007). The survey was collected by the Norwegian Institute for Labour and Social Research and the Uganda Bureau of Statistics between April and May 2007. It was the first comprehensive survey collected after the war ended and as households were moving out of camps. The survey

\footnotetext{
${ }^{3}$ Although this was a period when people were moving of their own volition, in later years,IDP return was partly influenced by forced closure of camp by authorities and pressure from owners of land in which IDPs were settled.
} 
covers Gulu, Kitgum, Amuru and Pader districts in the Acholi sub region, and Lira and Oyam districts in Lango (Figure 2) and is representative of all households that resided in IDP camps at some point during the conflict. The data were collected using a two-stage cluster design. The first stage involved obtaining full lists of IDP and return populations in the districts. The number of primary sampling units was then determined in respective locations. For households in camps, the units were camps where the settlements were small, or randomly selected geographic spots in each large camp. For return locations, the primary sampling units constitute one randomly selected village in each parish. In the second stage, four households at return sites and five households in camps from each of the selected units were randomly selected for interviews. In total, the survey covered about 3,984 households.

(Figure 2 about here)

Two main questionnaires were used. The household questionnaire was administered to the head of the household, their spouse or a responsible individual who was available at the time of the interview. It covered characteristics of the household and its individual members, information on demographic characteristics, housing conditions, education, household economy, health and displacement. The randomly selected individual questionnaire was answered by a randomly selected member of the household aged 16 years and older. It addressed issues pertaining to displacement, security, social and political situation.

\subsection{Armed Conflict and Locations Data-ACLED (2010)}

We merge household survey data with the Armed Conflict Events Data (ACLED). The latter provides detailed geo-referenced information and dates of village-level conflict episodes based on press reports and various publications (Karlsen, et al., 2010). This enables us to capture exposure of households to conflict episodes. The dataset defines an event in various ways; 1) a battle between government forces and rebel groups; 2) an attack either by the rebel group(s) or government forces on civilians; 3) a battle between rebel movements. For the case of northern Uganda, there was only one rebel movement since the 1990s, and therefore no events corresponding to the third definition. The data include a total of 3,233 events between 1997 and 2007 in the country, of which 1,661 took place in the surveyed districts (Lango and Acholi sub regions). In 2006, the data provide a total of 89 events in the districts while there were only four events between January and March 2007. During the time of the livelihood survey, there were no events reported. We believe this estimate to be an actual representation 
of events. This is because the period was largely peaceful, and the media is often interested in recording conflict events during peace talks.

\section{(Figure 3 about here)}

We use the data to construct two conflict intensity indices (see Bozzoli et al, 2011): One index reflects the intensity of conflict at the location expected place of return. Reports indicate that most households were returning to their home villages (Bjorkhaug,et al., 2007; Mabikke, 2011; Rugadya et al., 2008). This is likely to be the ancestral village of the head, given that access to land is mainly tied to family or clan ties (Mabikke, 2011). We only include events that took place in the surveyed districts. We base this decision on the notion that external events should not matter for household return. To construct the index, we use information about the geographic location of each event $\left(y_{i}\right)$ in that year derived from the ALCED database (Karlsen et al., 2010) as well as the location of the household $\left(h_{i}\right)$. We consider the year 2006 for two reasons. First, we can tell where the household was located during that year. Second, between January and March 2007 (shortly before the survey was collected), the data set recorded only 4 events in two districts, and no events in four districts. We then estimate the absolute square of the distance $\left(d^{2}\right)$ in degrees between the household and each of the events. This is defined as; $d^{2}\left(y_{i}, h_{i}\right)=\left\|y_{i}-h_{i}\right\|^{2}$. The resulting index $\left(C\left(h_{i}\right)\right)$ is obtained by aggregating events in a given year and discounting them by their respective distances from the household.

$C\left(h_{i}\right)=\sum_{i=1}^{I} e^{-\alpha\left(d^{2}\left(y_{i}, h_{i}\right)\right)}$

The parameter $\alpha$ is a distance-discount factor. Different values of $\alpha$ evaluate the potential influence of respective events on the household. The larger the value, the less relevant the distant conflict events may be to the household's point of view, while a lower value attaches more importance to these events. We constructed indices for different values of $\alpha$ and selected the index that maximizes the log likelihood function. In our case, $(\alpha=10)$ offered the best fit.

The GPS coordinates for the location of the household in 2006 are used to construct the index for place of residence in 2006, while the other index is computed using coordinates for the expected place of return. We focus exclusively on events that involved gun shots, rebel 
activity and activities by the national army, and disregard encounters that took place outside the study area. Czeika and Kis-Katos (2009) indicate that insecurity creates additional costs that modify the expected outcome and that it reduces the relevance of other factors that may influence migration. Following this argument, we expect conflict intensity to discourage household return.

\section{Modeling return}

Following the household migration theory, we posit that returning as a large unit would pay off more than as an individual, given the uncertainties associated with re-integration. Most households in Northern Uganda tend to settle in their communities of origin. As noted in section 4.2, settlement patterns are related to the fact that households access land under the clan or customary system. Access to land may be easier for families rather than individuals. A recent report on land policy and administration in the region (Rugadya et al., 2008) reveals a high prevalence of land disputes among returnees. Given this challenge, returning to the community as a household rather than an individual may facilitate access, security and legitimacy over land.

In the remainder of this section, we closely follow the theoretical model of Deininger et al. (2004), although we make some modifications for the case of Uganda. We account for the possibility of recent exposure to violence around the camp and return areas. We recognize that there might be spatial heterogeneity in the intensity of violence, which we proxy for with an indicator of armed conflict events described in section 4.2. For the case of leaving the camp, we label this indicator $r$, and we consider that it may negatively affect utility.

A household $i$ finances consumption $\left(g_{i}\right)$ with two resources: income $\left(q_{i}\right)$ and wealth $\left(W_{i}\right)$. Income is generated through various sources of activity (cultivation, herding, trading). We assume that income $q_{i}$ is a function of accumulated (previous) skills in different activities. Let $S_{i}$ denote a vector of skills (proxied by having been involved in different activities). Then, abstracting from other factors (household demographics, community characteristics, $H$ ), we have $q_{i}=q\left(S_{i}\right)$. Households can also use wealth to meet the budget constraint:

$q_{i}+W_{i} \leq g_{i}$ 
Thus, the indirect utility from leaving the camp is:

$V_{\text {leaving }}\left(r, W_{i} ; H_{i}, S_{i}\right)$

Recall that the household has the option to stay in the camp or leave, at least by the time of the survey (Ofxfam, 2008; USAID, 2007; USAID,2008). However, camps may not be entirely safe. In Uganda, there was evidence of insecurity in IDP camps, although the likelihood was minimal. Stites (2006) notes that the protection of civilians in the camps was not effective, as many rebel attacks and waves of abduction occurred during the time when communities were in camps. We argue that the likelihood of violence while staying in a camp may also affect utility, and we label it $x$.

In spite of challenges faced in confinement, households can generate income $\left(y_{i}\right)$ while in camps through, for instance, (limited) agricultural opportunities, trading activities, and sale of donations (e.g. food, unused seeds). We assume that $y_{i}$ also depends on skills, so that $y_{i}=y\left(S_{i}\right)$. Income is complemented with assistance $\left(z_{i}\right)$ they receive from government and relief agencies. Then, if the household chooses to stay, its budget constrain will consist of income and transfers, so that:

$z_{i}+y_{i}\left(S_{i}\right) \leq g_{i}$

The indirect utility from staying is then:

$V_{\text {staying }}\left(x, z_{i} ; H_{i}, S_{i}\right)$

The location decisions will be made basing on the utility a household expects to derive. A household will return if:

$V_{\text {leaving }}\left(r, W_{i} ; H_{i}, S_{i}\right)>V_{\text {staying }}\left(x, z_{i} ; H_{i}, S_{i}\right)$

One can $(\log )$ linearize both indirect utility functions to set up an additive random utility model to model the probability of return, as we do in the next sections. 


\section{Empirical specification}

Let $y^{*}$ be the difference in the lifetime utility (V) between leaving and staying. In our empirical setting, $y^{*}$ is parametrized as a linear function of explanatory variables, which proxy for arguments in section 5, the unknown vector of parameters $(\beta)$ and a disturbance term $(\varepsilon)$, which is assumed to be normally distributed.

$y^{*}=\beta_{1} H h+\beta_{2}$ Econ $+\beta_{3} \operatorname{Serv}+\beta_{4} \operatorname{Conf}+\varepsilon$

The outcome of the decision to leave or not can be summarized in a "response" variable $\mathrm{y}=\{(1),(0)\}$. The household will leave if $\mathrm{y}^{*}>0$ and stay otherwise. That is,

$y=\left\{\begin{array}{l}1 \rightarrow y^{*}>0 \\ 0 \rightarrow y^{*} \leq 0\end{array}\right.$

The survey questionnaire lists three categories of households. The first category includes 2,135 (53.59\%) households that were full-time residents in the camp. The second includes 1,573 (39.48\%) households that had permanently moved out of camps or settled in transit sites (closer to home), while the third includes 276 (6.93\%) households that commuted between camps and return (or transit) sites. We categorise a household as a commuting household if at least $50 \%$ of the members in the household commuted. This accounted for 56 households in Lango sub region and 220 households in Acholi. Since households in this category spent most of their time in camps, we posit that they were not excluded from services provided in the camps. For most of our analysis, we consider them among camp residents. Later, in section 8 , we redefine the classification to check for robustness of our results.

The vector $H h$ controls for household characteristics. These include household size, gender of the household head, age of the head, and proportion of young members (below 15 years) in the household. The second set of variables (Econ) controls for economic skills that may be relevant for recovery. We particularly consider whether the head of the household cultivated, reared animals; engaged in trading or made handicrafts in the past one or two years ${ }^{4}$. We also separately include variables that capture a history of involvement of any

\footnotetext{
${ }^{4}$ We exclude the current year to avoid potential endegeneity.
} 
members in economic activities. These include: whether at least one member of the household was involved in cultivation, trading, herding or making handicrafts in the past one year, or involved in the respective activities in the previous two years. These past experiences could influence camp decongestion, as households may seek to relocate to areas where markets may facilitate these activities.

The vector Serv captures the presence of facilities in camps. While it represents the current camp situation for IDPs, it also represents previous camp situations for households already in return sites $^{5}$. During displacement, development agencies tend to provide a host of services to displaced households. Continued provision of these services during transition to recovery may discourage camp decongestion especially if the relevant services do not exist or are inadequate in return areas. We include dummy variables to investigate whether existence of facilities such as markets, primary schools, secondary schools and health services have an effect on the probability of moving out of camps.

Conf is a vector of variables that capture the effect of violent conflict. In addition to the conflict intensity indices described in section 4.2 , the vector includes a control for duration in the IDP camp (in years). We also control for the effect of recent conflict-relate deaths in the household, proxied by an indicator of whether a household lost an economically active member (aged 15-64) due to conflict or conflict-related illness in the past two years.

\section{Descriptive evidence}

Tables 1 and 2 provide a description of variables and a summary of the full sample. Evidence in the survey indicates a high degree of camp decongestion in the Lango sub region $(65 \%)$ compared to the Acholi sub region, where 23\% had moved out of camps (Table 3). On average, households were displaced for 7 years. The striking observation is that communities that were displaced much later by the insurgency had higher adjustment rates. On average, households in the Lango sub region had been displaced for about four years compared to nine years for households in Acholi.

Districts in the Acholi sub region registered the highest proportion of camp residents (Figure 4). Kitgum district had about $95 \%$ of the households still residing in camps followed by Amuru district (about $81 \%$ ) and Gulu (about 73\%) at the time of the survey.

\footnotetext{
${ }^{5}$ In the survey instrument, the question is posed as: "In the IDP camp where you live/ used to live, are there any of the following services?"
} 
We also observe a higher proportion of households headed by females residing in IDP camps $(29 \%)$ compared to households that moved $(20 \%)$. Over $70 \%$ of the households had access to camp services, particularly water, health facilities, markets, and primary schools. This proportion was higher for camp residents (table 2).

Returnee households have more educated heads compared to those that stayed. $40 \%$ of household heads in IDP camps have no education while they account for about $30 \%$ among returnee households. About $44 \%$ of the heads in camps have primary education and $15 \%$ have at least secondary education. This is lower when compared with about $53 \%$ and about $18 \%$ respectively for returnee households.

\section{(Table 1 about here)}

With regard to activity histories, overall about $10 \%$ of the household heads had a history of cultivation in the previous year, and the proportion was higher for residents in the camp (table 2). 16 percent of the total sample had heads with history of herding in the past year, and this was more profound among returnee households. More heads with a history of trading were found in camps.

The conflict indices for place of birth and place of origin reveal greater exposure for households residing in camps (Table 2). Conflict intensity at the location of camp residents in 2006 is 2.4 units higher than for households that left the camps (2.65 compared to 5.09 units respectively). Intensity of conflict at the expected place of return is higher for those still staying in camps.

A comparison between the two sub regions also shows marked differences. The conflict index for location in 2006 is higher for households in the Acholi sub region than in Lango, while the difference is higher in Acholi for conflict intensity at the expected place of return.

(Table 2 about here) 


\section{Regression results}

In this section, we estimate different specifications to analyse the effect on the dependent variable for varying sets of controls. The first specification includes conflict indicators. In the second, we introduce household characteristics. In specification three, we control for accumulated economic skills. The fourth introduces indicators for access to facilities in camps. Lastly, we interact indicators of access to facilities with household composition. All specifications control for district fixed effects.

\section{Effect of recent conflict on residence status}

As seen in Table 3, conflict proxies strongly influence the decision to move out of the camp. The indicators remain negative and highly significant, even when controls are included in the model. A longer period of displacement reduces the likelihood of households to leave the camp. This observation concurs with findings by Deininger et al (2004) that a long duration of displacement may discourage return. A long period of displacement could have a number of effects. The associated loss of livelihoods may perpetuate dependence on relief aid, which households may not expect on return. Living longer in the camp may also erode expectations on recovery, thereby discouraging return.

\section{(Table 3 about here)}

The two conflict intensity indices are associated with a reduction in the probability of leaving the camp. This relationship remains negative after adding controls in the next specifications. Recent insecurity in camps and return locations could encourage households to stay longer in camps, where protection is more guaranteed. While the index for location in 2006 is highly statistically significant overall, it has no effect on individual models for the Acholi and Lango regions (table 7). The possibility of leaving the camp is also low for households that lost at least one economically active member due to violent conflict. This is plausible given that a reduction in human resources may increase the cost of adjustment during return.

\section{Past economic experiences and residence status}

Results indicate that past experience of the head in animal rearing is positive and strongly significant across specifications (table 3). In table 4, we find that involvement (of any member including the head) in cultivation or herding in the past one year increases the 
probability of a household leaving the camp, compared to a household without any experience in them. Cultivation in the two years preceding the survey also increases this likelihood. It could be reasonable to argue that the experience in these activities may encourage households to leave camps, where competition for land is high. This move could be driven by expectations of better opportunities to improve livelihoods in retun locations, where resources such as land are in abundance. In our recent work (Bozzoli et al., 2011), we found that individual expectations are high for individuals who were recently active in economic activities. On the other hand, households whose skills have been eroded would find it hard to adjust if they were to return.

\section{(Table 4 about here)}

In contrast, past skills of the head in trading activities discourage camp decongestion. A similar effect emerges for households whose members (including the head) were involved either during the past one or two years. A possible explanation could be that inadequacy of product markets in return areas may reduce employment options of households that have recently been active in trading. We also find similar findings in the Acholi and Lango sub samples (table 5).

\section{(Table 5 about here)}

\section{Does presence of facilities in IDP camps deter return?}

Facilities in camps turn out to be important in influencing return decisions (table 3 ). The indicator for existence of water is negative although weakly significant at the $10 \%$ level in specifications iii and iv. Presence of primary and secondary school also reduces the probability that a household will leave the camp. In the last specification, we interact camp facilities with the proportion of young members in the household. We base this on the premise that,much as facilities are important to the household as a whole, they could matter more for certain age categories. The interaction terms for access to markets is significant and negative. This implies that in the presence of markets, the likelihood of leaving the camp is low for a household with a high proportion of members below 15 years of age. Interacting the indicator for primary and secondary schools with the proportion of young members also yields a negative and significant effect: this is expected since households with a large proportion of individuals of school-going ages may value this type of infrastructure more than other 
households. Generally, we observe a similar pattern for the Lango and Acholi sub regions (table 6).

(Table 6 about here)

\subsection{Robustness checks}

In table 3, the indicator for camp residence includes households that commuted between camps and return sites. This category was included in the IDP category because they benefited from services provided in camps. However, it could be the case that households that commute may possess inherent characteristics that could facilitate them to partially relocate, compared to permanent residents in camps or return sites. As a robustness check (Table 7), we exclude them from the sample and estimate a probit regression where the residence status variable now equals 1 if a household permanently left the camp and zero if still in the camp. Apart from the minimal differences in the size of the coefficients, the results remain largely comparable.

\section{(Table 7 about here)}

In table 8 , we estimate a multinomial logit regression for three decisions, namely: stayed in the camp, moved to the place of origin (Home), or moved into a transit site close to the place of origin (Transit), and the results are consistent with our main probit results. For instance, we find that conflict variables are negatively associated with choosing to relocate to origin or transit site compared to staying in the camp.

\section{(Table 8 about here)}

Note that our conflict indices exclude events that were external to the study area. In order to argue with confidence that the decision to move was only influenced by internal conflict events, rather than external ones, events that are external to the survey districts should not matter for return. Thus, it is important to investigate whether these events had a bearing on return decisions. Table 9, presents two sets of indices capturing events that are external to the six districts. In the first set, we capture 91 events that took place in other parts of the country, for location in 2006 and expected place of return, respectively. However, in the results we find no significant effect on return decisions. Next, we construct indices for 49 events in neighboring DRC, Southern Sudan and CAR, and the effect turned out insignificant. Lastly, when all events are considered, the results remain consistent with our main results. 
This confirms our position that the decision to leave the camp was independent of external events.

\section{(Table 9 about here)}

\section{Conclusions}

The study examines the factors that influence household decisions to leave internal displacement camps in the immediate aftermath of violent conflict. We merge data from the northern Uganda Livelihood Survey (2007) for households that were at any one time displaced by violent conflict with geo-referenced conflict event data to identify possible drivers of return decisions.

From the results, it is apparent that the exposure to recent violent conflict episodes plays an important role in influencing household decisions to reintegrate. High intensity of conflict around camps may signal uncertainity in the return process. Households may therefore opt to remain in camps where protection may be more guaranteed. A rational household will factor in the security situation at the return site before choosing to move. As expected, our results indicate that the household will most likely choose to move out of the camp in the event of less exposure to violent conflict at the return site. Recent exposure to conflict creates uncertainities among households. It may also result in negative expectations about return to normalcy, thus delaying the early post-conflict reconstruction effort.

We confirm recent findings that longer displacement periods could offer disincentives for reintegration after conflict. This could in part result from high levels of acculturation and creation of stronger networks in host communities. Inactiveness that results from staying longer in camps could also increase vulnerabilities, such that staying in camps could offer safety nets for household survival.

We also find that the presence of services in displacement sites may play an important role in informing location decisions of households. The availability of educational and health facilities in IDP camps may discourage camp decongestion. The assessment of different age categories reveals that the significance of camp services varies with household composition. For instance, households with a higher proportion of children below 18 years are more likely to stay in camps, if there is access to primary schooling in camps. This result may reflect the likely difficulties associated with access to resources for households with a small active labour force in the event of return. We observe that access to education services may be important for households with more school-age children. Households with a higher 
proportion of young members are more likely to stay in camps in the presence of primary schools. The key policy lesson here is that social service provision in return sites is key to IDP return. Recovery initiatives need to ensure access to adequate infrastructure in return sites if reintegration and camp decongestion efforts are to yield faster results. Delayed provision of the services may increase cost of return and slow down the recovery process.

Previous skills may also be crucial during the camp decongestion process. Our findings show that households whose heads had past experience in herding were more likely to leave camps. This is not surprising, given that conditions around camps may not facilitate active participation in certain welfare enhancing activities, the period of peace may provide an opportunity for households to re-establish their status quo outside camps. Experience in trading on the other hand discourages return, probably owing to advantages of trading opportunities around camps. For activities that require active markets, return areas may not provide incentives during the early period of return. In such cases, transaction costs are very low around camps, where population is high and relevant structures exist. Reintegration initiatives need to ensure access to vital infrastructure in return areas to enhance livelihood reconstruction.

It is imperative to note that war may create new realities, such that returning to a prewar economy may be challenging. The associated wave of displacement results in new settlement patterns that households may not easily be given up. 


\section{References}

Badurdeen, F.A.,2010. Ending internal displacement: The long-term IDPs in Sri Lanka. Refugee Studies Centre, Working Paper Series No. 66.

Bailey A J. and T. J, Cooke 1998, Family migration and employment: the importance of migration history and gender. International Regional Science Review, 21 (2) 99-118.

Bjorkhaug, I., B. Morten, A. Hatloy, and K. M. Jennings. 2007. Returning to uncertainity? Addressing vulnerabilities in Northern Uganda. United Nations Development Programme.

Blattman, C. and J. Annan, 2010. The consequences of child soldiering. Review of Economics and Statistics, 92(4), pp. 882-898.

Borjas G J and B., Bratsberg, 1995, "Who leaves"? The outmigration of the foreign born. Review of Economics and Statistics, 78, pp. $165-176$.

Bozzoli, C., and T. Brück, 2010. Child morbidity and camp decongestion in post-war Uganda. MICROCON Research Working Paper 24.

Bozzoli, C., T. Brück, and T. Muhumuza, 2011. Does war influence individual expectations? Economics letters, 113, 288-291.

Brown, M., 2006. "The failing humanitarian response in Northern Uganda". In the crisis in Northern Uganda, Humanitarian exchange, Number 36.

Brück, T. 2004. Coping strategies post-war rural Mozambique, HiCN Working Paper 2, Households in Conflict Network, www.hicn.org.

Bundervoet, T. and P. Verwimp, 2005, Civil war and economic sanctions: An analysis of anthropometric outcomes in Burundi, HiCN Working Paper no. 11, Households in Conflict Network, University of Sussex, UK (www.hicn.org).

Collier, P., L. Elliot, H. Hegre, A. Hoeffler, M. Reynal-Querol, and N. Sambanis, 2003. Breaking the conflict trap: Civil war and development policy. In A co-publication of the World Bank and Oxford University Press.

Crisp, J., 2010. Forced displacement in Africa: Dimensions, difficulties and policy directions. Refugee Survey Quarterly, 29 (3), pp. 2-27.

Czaika, M., and K. Kis-Katos, 2009. Civil conflict and displacement: Village-level determinants of forced migration in Aceh. Journal of Peace Research 46, pp. 399-418 
Deininger, K., A. M. Ibáñez and P. Querubin, 2004. Towards sustainable return policies for the displaced population: Why are some displaced households more willing to return than others? Households in Conflict Network. Working Paper 07, February 2004.

Djuraskovic I. and N. Arthur, 2009. The acculturation of former Yugoslavian refugees, Canadian Journal of Counselling, 43 (1), pp. 18-34.

Ferris E., N.M.Birkeland, N. Sluga, N.Wahcki, S.D. Miller, 2011. Local integration of internally displaced persons in protracted displacement: some observations: Ed. Ferris, E., Resolving internal displacement. Prospects for local integration. Brookings institute.

Fiala, N., 2011. Recovery or trapped in poverty? The economic consequences of forced displacement in northern Uganda. University of California, Irvine, Mimeo.

González, M. A. and R. A. Lopez, 2007. Political violence and farm household efficiency in Colombia. Economic Development and Cultural Change 55(2), pp: 367-392.

Government of Uganda, 2008. Camp phase-out guidelines, Office of the Prime Minister, May 2008.

Harris, J.R. and M. P. Todaro. 1970. Migration, unemployment and development: A twosector analysis. American Economic Review, 60, pp. 126- 142.

Hoeffler, A., 2008. Dealing with the consequences of violent conflicts in Africa. Background Paper for the African Development Bank Report 2008.

Hovil, L. and O. Bueno, 2011. Resisting repatriation: Burundian refugees struggling to stay in Tanzania. International Refugee Rights Initiative, September 2011.

Ibáñez A. M. and C.E. Velez, 2007. Civil conflict and forced migration: Micro determinants and the welfare loses of displacement in Columbia. World Development, 36(4), pp. 659676.

International Crisis Group, 2008. Timor-leste's displacement crisis. Asia Report No. 148, 31 March 2008.

Internal Displacement Monitoring Centre, 2008. Focus shifts to securing durable solutions for IDPs: A profile of the internal displacement situation. November, 2008.

Internal Displacement Monitoring Centre, 2009. Internal displacement: Global overview of trends and developments in 2008, April 2009.

Internal Displacement Monitoring Centre, 2010a. Uganda: Difficulties continue for returnees and remaining IDPs as development phase begins. December 28, 2010.

Internal Displacement Monitoring Centre, 2010b. Peace, Recovery and Development: Challenges in Northern Uganda. March 2010. 
Internal Displacement Monitoring Centre, 2011. Internal displacement: Global overview of trends and developments in 2010, March, 2011.

International Organization for Migration, 2011. Emergency needs assessments. Displacement of Christians to the north of Iraq. 31 January 2011.

Jacobsen, K., A. Marshak, A. Ofori-Adjei and J. Kembabazi, 2006. Using microenterprise interventions to support the livelihoods of forcibly displaced People: The impact of a microcredit program In IDP camps in lira, Northern Uganda. Refugee Survey Quarterly, 25 (2), pp. 23-39.

Justino P., 2011. The impact of armed civil conflict on household welfare and policy. IDS Working Paper. Volume 2011, No. 384.

Justino, P. and P. Verwimp, 2006. Poverty dynamics, conflict and convergence in Rwanda, HiCN Working Paper 16, Households in Conflict Network, www.hicn.org.

Karlsen J., H. Hegre, A. Linke and C. Raleigh, 2010. Introducing ACLED: An Armed Conflict Location and Event Dataset. Journal of Peace Research, 47(5), pp. 651-660.

Kalyvas, S. N. 2006. The logic of violence in civil war, Cambridge studies in comparative politics. Cambridge; New York: Cambridge University Press.

Knoeche, D., 2010. Profiling of IDPs affected by the conflict in Saa'da Yemen. Survey Commissioned by UNHCR to DRC.

Koser, K.,1993. Repatriation and information: A theoretical model, in Black, R. and V. Robinson, (eds.) Geography and Refugees: Patterns and Processes of Change. London: Belhaven Press.

Koser, K., 1997. Information and repatriation: The case of Mozambican refugees in Malawi. Journal of Refugee Studies, 10 (1 ), pp. 1-18.

Land and Equity Movement in Uganda, 2006. Return or transformation? Land and the resettlement of IDPs in Northern Uganda. Policy Discussion Paper 6.

Mabikke, S.B., 2011. Escalating land grabbing in post-conflict regions of Northern Uganda: A need for strengthening good land governance in Acholi region. Paper presented at the International Conference on Global Land Grabbing. University of Sussex, 6-8 April 2011.

Massey, D.S., Arango, J., Hugo, G., Kouaouci, A., Pellegrino, A. and J.E. Taylor, 1993, 'Theories of international migration: Review and appraisal', Population and Development Review, 19, pp.431-467. 
Mesnard, A., 2009. Migration, violence and welfare programmes in rural Colombia. IFS working Paper W09/19. September 2009.

Mincer, J. (1978), 'Family migration decisions,' Journal of Political Economy , 86, pp. 749773.

Navratil, F.J. and J.J. Doyle, 1977, 'The cocioeconomic determinants of migration and the level of aggregation', Southern Economic Journal, 43, pp.1547-1559.

OCHA, 2007. Uganda humanitarian situation report. November 1 - 302007.

Ojeda, S., 2010. The Kampala convention on internally displaced persons: Some international humanitarian law aspects. Refugee Survey Quarterly, 29, (3), pp. 58-66.

Orrenius P.M, 1999. Return migration from Mexico: Theory and evidence $\mathrm{PhD}$ thesis, University of California, Los Angeles, CA.

Oxfam, 2008. From emergency to recovery. Briefing Paper, September 2008.

Oxfam, 2010. IDPs in eastern Chad: is it time to go back home. Joint report with Care international, ACTION FAIM and Cordaid.

Pantuliano, S., M. B-Smith and P. Murphy, 2007.The long road home: opportunities and obstacles to the reintegration of IDPs and refugees returning to Southern Sudan and the three areas. Humanitarian Policy Group, Overseas Development Institute. Report of Phase I, August, 2007.

Rabenhorst, C., K. Cartwright,M. Baskin, E. Hoxhaj and S. Karadjic, 2003. "I was born in that village": prospects for minority returns and sustainable integrated communities in Kosovo.Report prepared for Kosovo Returns Assessment: USAID Contract No. LAG-I00-99-00036-00.

Reilly, R., and Risser, G., 2000. Return, resettlement and reintegration: application of the guiding principles on internal displacement: An Asia case study. Refugee Survey Quarterly, 19 (2), pp. 170-190.

Rogge, J. R. and J. O. Akol, 1989. Repatriation: Its role in resolving africa's refugee dilemma, International Migration Review, 23 (2), pp. 184-200.

Rugadya, M. A., E.N. Gayiiya and H. Kamusiime, 2008. Uganda land study. Analysis of post conflict land policy and land administration: A survey of IDP return and resettlement issues and lesson: Acholi and Lango regions. Prepared for the World Bank, to input into Northern Uganda Peace, Recovery and Development Plan (PRDP) and the Draft National Land Policy. 
Shemyakina, O., 2006, The effect of armed conflict on accumulation of schooling: Results from Tajikistan, HiCN Working Paper no. 12, Households in Conflict Network, University of Sussex, UK (www.hicn.org).

Shewfelt, 2007. Rebuilding community after conflict: Internally Displaced People in Indonesia. Prepared for delivery at the 2007 Annual Meeting of the American Political Science Association, August 30th- September 2nd, 2007.

Stark, O., 1993. The Migration of Labour, Cambridge: Blackwell.

Stark, O. and Bloom, D., 1985, 'The New Economics of Labour Migration (NELM)', American Economic Review, 75, pp. 173-178.

Stark, O.,1984. Rural-to-urban migration in less developed countries: A relative deprivation approach, in The migration of Labor, by Oded Stark, 1991, Basil Blackwell, Oxford and Cambridge, MA, pp. 87-101.

Stark, O. and Yitzhaki, Shlomo, 1988. "Labor migration as a response to relative deprivation", in The migration of Labor, by Stark, O., 1991, Basil Blackwell, Oxford and Cambridge, MA, pp. 102-118.

Stites, E., 2006. Humanitarian agenda 2015: Northern Uganda country study: Feinstein International Center. Briefing paper.

Todaro, M.P., 1976, Internal migration in developing countries: A review of theory, evidence, methodology and research priorities, Geneva, Switzerland: International Labour Office.

Todaro, Michael P. and Lydia Maruszko. 1987. Illegal migration and US immigration reform: A conceptual framework. Population and development review, 13, pp. 101-114.

Turnip, S. S. (2003). "Going home or going away from home? The dilemma of Madurese IDPs." Researching Internal Displacement: State of the Art. Trondheim, Norway, Forced Migration Review Supplement Issue Conference Report: 35-36.

UNICEF, 2006. The state of youth protection in Uganda. Kampala: Unicef.

United Nations, 2009. Trends and impacts in conflict settings: The socio-economic impact of conflict-driven displacement in the ESCWA region. Economic and Social Commission for Western Asia (ESCWA). Issue No. 1. 12 March 2009.

USAID, 2006. Uganda - Complex emergency. Situation Report No. 3, Fiscal Year, 2006.

USAID, 2007. Uganda - Complex emergency. Situation Report N0.1, Fiscal Year (FY) 2007.

USAID, 2008. Uganda- Complex emergency. Situation Report N0.2, Fiscal Year (FY) 2008.

United States Institute of Peace, 2011. Refugees and IDPs after conflict: Why they do not go home. Special Report 268, April, 2011. 
Verwimp, P., 2005. An economic profile of peasant perpetrators of genocide: Micro-level evidence from Rwanda", Journal of Development Economics 77: 297-323.

Verwimp, P. and J. van Bavel, 2005, Child survival and the fertility of refugees in Rwanda after the genocide", Special Issue of the "Demography of Violent Conflict". European Journal of population, 21(2-3), pp. 271-290.

Vinck, P. and P. Pham, 2009. Peace building and displacement in Northern uganda: A crosssectional study of intentions to move and attitudes towards former combatants. Refugee Survey Quarterly, 28(1), pp. 59-77.

Voors M., E., Nillesen, P., Verwimp, E., Bulte, R., Lensink and D., van Soest, 2010. Does conflict affect preferences? Results from field experiments in Burundi. MICROCON Research Working Paper 21.

WFP Uganda, 2003. Uganda situational report, $1^{\text {st }}-31^{\text {st }}$ December, 2003: Targeted food assistance for relief and recovery of refugees, internally displaced persons and vulnerable groups in Uganda. December, 2003.

Yang, D., 2004. Why do migrants return to poor countries? Evidence from Philippine migrants' responses to exchange rate shocks. University of Michigan, Mimeo. 
Figure 1. The trend of internal displacement in Northern Uganda

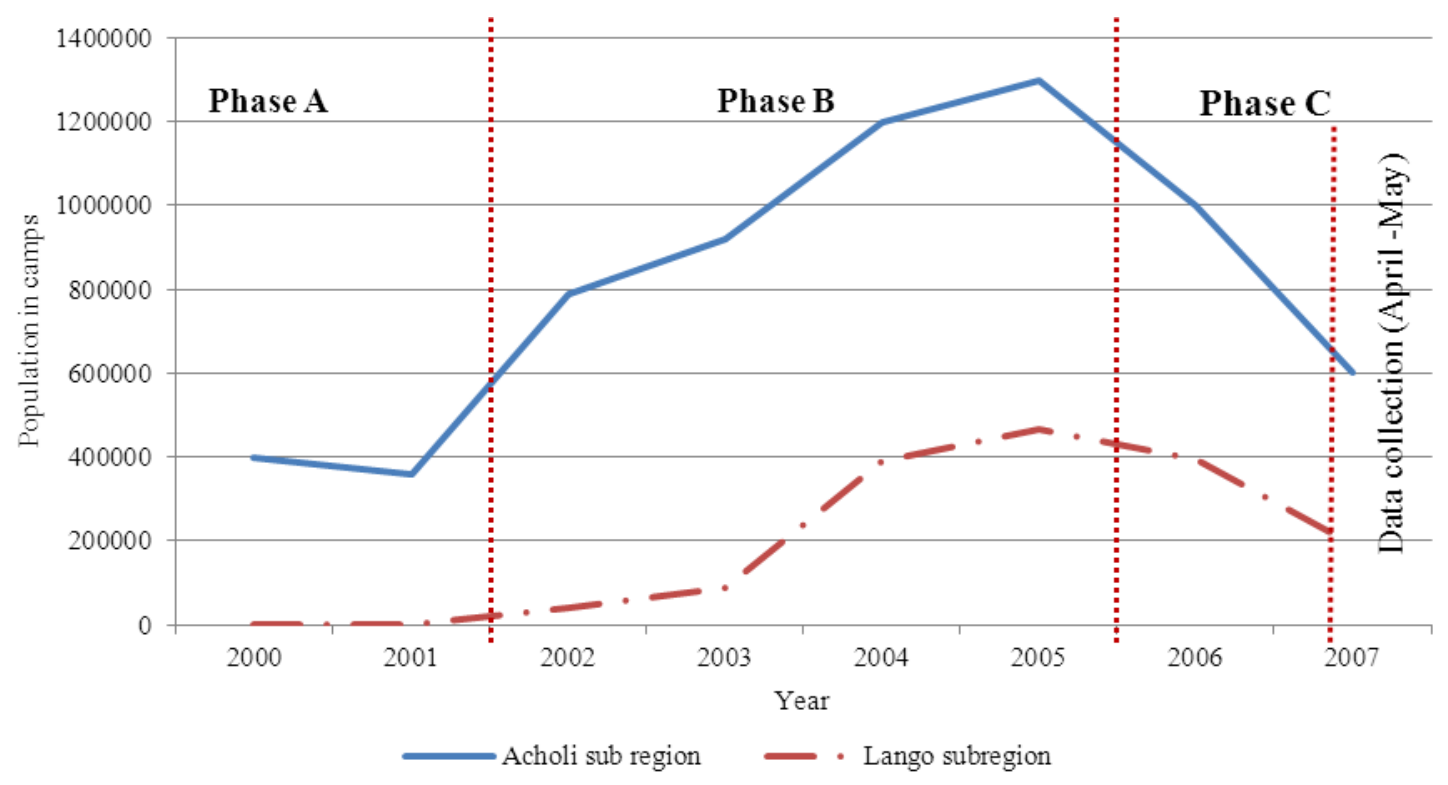

Notes: The figure represents the estimates of the population in IDP camps in Lango and Acholi sub regions (This represents a stock, not a flow). The estimates were obtained from various agency reports (IDMC 2009; 2010b; OCHA, 2007; United Nations, 2009; USAID, 2006; WFP Uganda, 2003). Information on the number of people displaced in the period preceding 2000 may not be reliable to report due to existence of few relief agencies and frequent movement of people between displacement cites and homes in response to intensity of conflict. The estimates only consider individuals in designated camp locations. Nonetheless, available evidence provides a close picture of internal displacement and return, which may coincide with intensity and spread of the conflict. Phase A represents the period when the conflict was concentrated in Acholi sub region. This excludes displacements that occurred before 2000. Phase B constitutes the acceleration of the conflict and the spead to Lango and other sub regions, following "Operation Iron fist" in Southern Sudan. Phase C was a period of peace talks and the end of violent conflict. 
Figure 2. Districts covered by Northern Uganda Survey (2007)

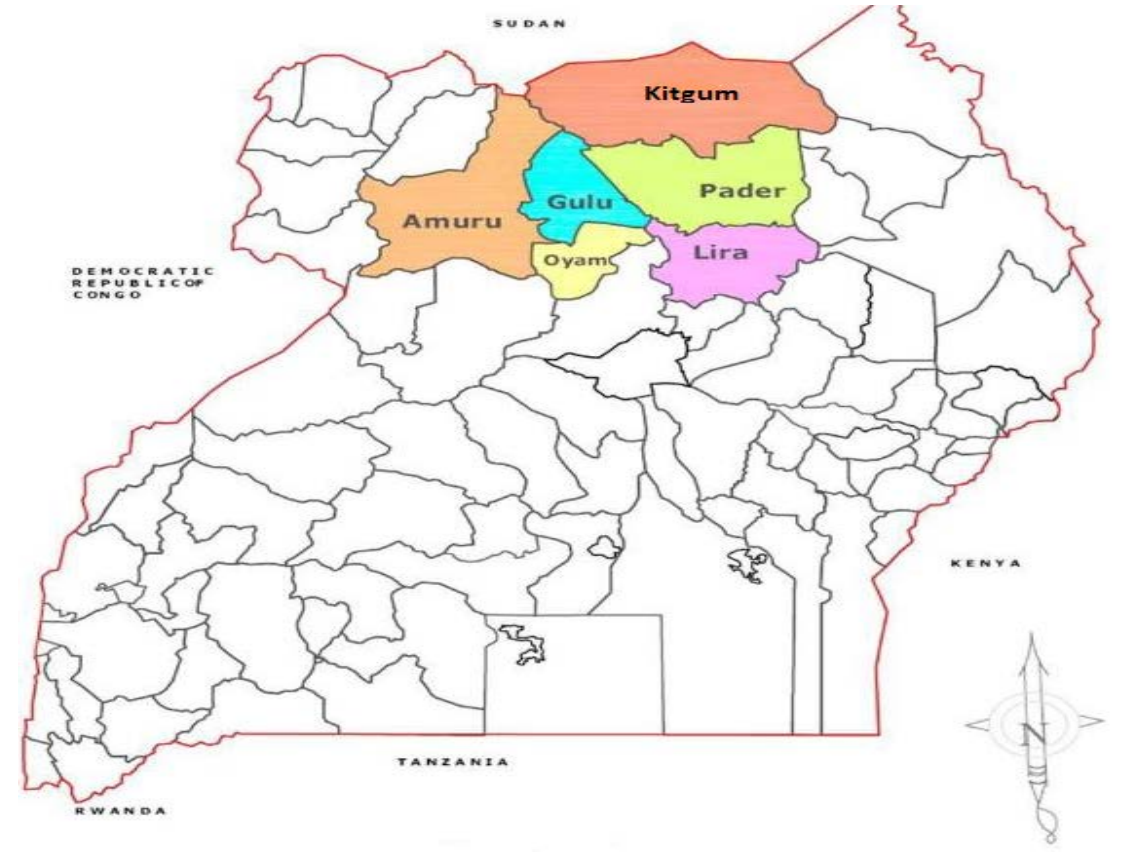

Figure 3. Average number of conflict events in Acholi and Lango sub regions (1997-2007)

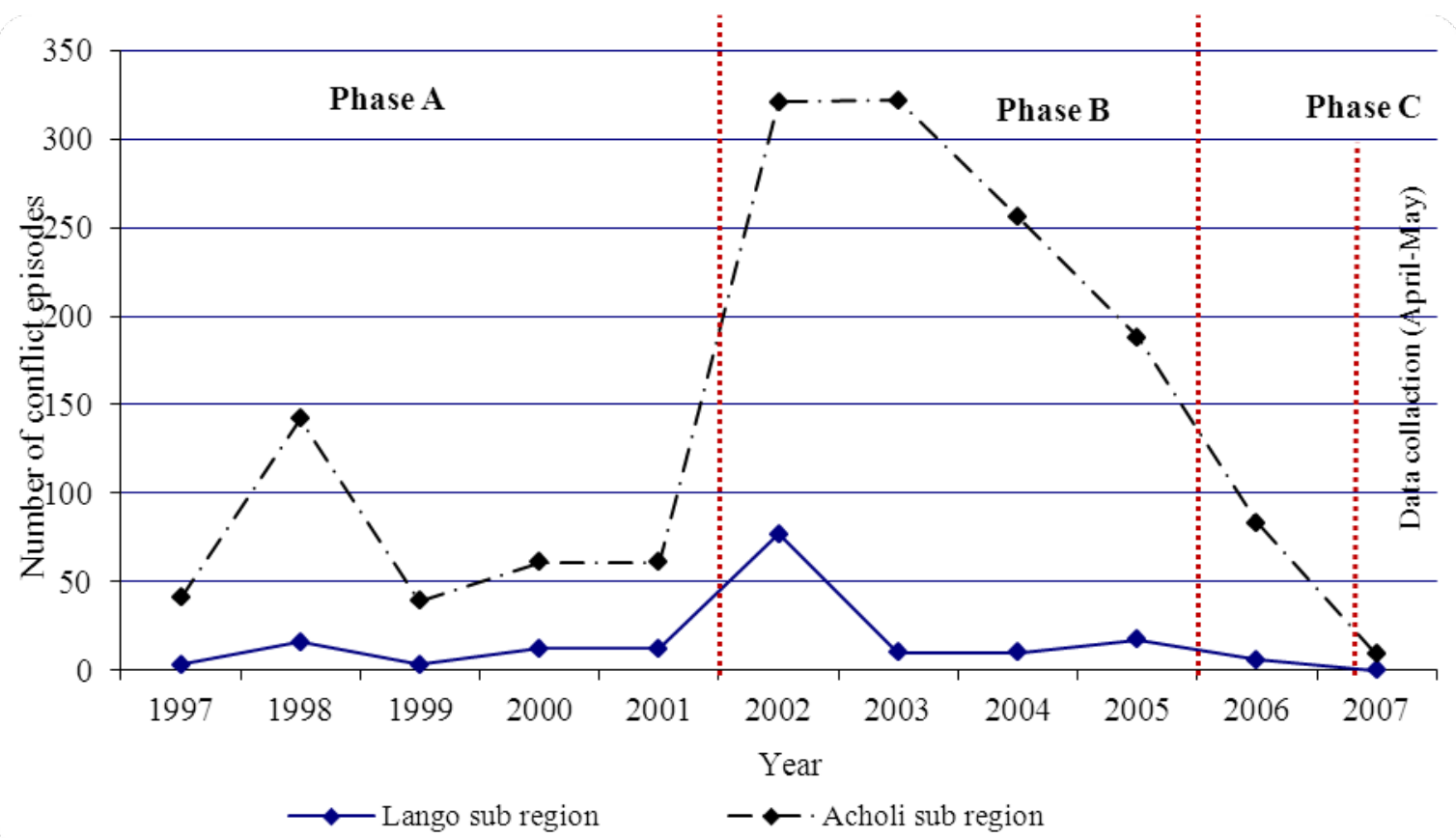

Notes: Source: authors' computations using Armed Conflict and Events data -ACLED (2010). Phase A represents the period when the conflict was concentrated in Acholi sub region. The figure excludes events that occurred before 1997, which could also constitute to this phase. Phase B constitutes the acceleration of the conflict, and spread to Lango and other sub regions, following "Operation Iron fist" in Southern Sudan. Phase C was a period of peace talks and the end of violent conflict. 
Figure.4. Shares of camp decongestion in surveyed districts.

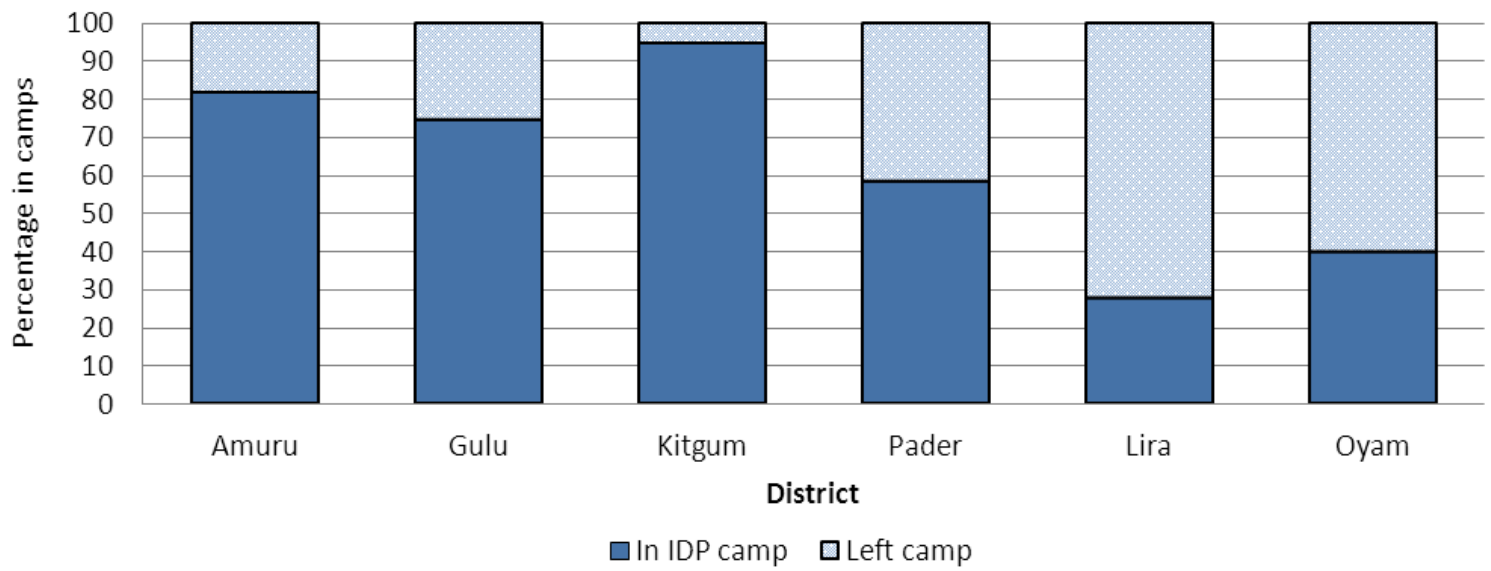

Notes: Estimates based on the weighted sample.

Table 1. Description of variables and summary statistics (full sample)

\begin{tabular}{|c|c|c|c|}
\hline Definition & Variable type & Mean & Std Dev \\
\hline $\begin{array}{l}\text { Mean duration in IDP camp in years } \\
\text { Member ( } 15-64 \text { years) died in the past } 2 \text { years } \\
\text { Conflict intensity at location in } 2006 \\
\text { Conflict intensity at origin in } 2006\end{array}$ & $\begin{array}{l}\text { Continuous } \\
\text { Discrete } \\
\text { Count } \\
\text { Count }\end{array}$ & $\begin{array}{l}6.768 \\
0.013 \\
4.123 \\
4.015 \\
\end{array}$ & $\begin{array}{l}4.118 \\
0.110 \\
4.357 \\
4.104\end{array}$ \\
\hline Age of household head & Continuous & 42.37 & 15.242 \\
\hline Head is female & Discret & 0.252 & 0.417 \\
\hline Size of the household & Continuous & 5.773 & 2.572 \\
\hline Ratio of males to females & Continuous & 1.238 & 1.150 \\
\hline Head is single & Discrete & 0.027 & 0.159 \\
\hline Head is married & Discrete & 0.744 & 0.421 \\
\hline Head is widowed/divorced & Discrete & 0.229 & 0.403 \\
\hline Head has no formal education & Discrete & 0.361 & 0.481 \\
\hline Head has primary education & Discrete & 0.476 & 0.500 \\
\hline Head has secondar eduction & Discrete & 0.163 & 0.354 \\
\hline Proportion of the young (below 18) & Continuous & 0.551 & 0.222 \\
\hline Head ever cultivated & Discrete & 0.103 & 0.215 \\
\hline Head ever herded & Discrete & 0.160 & 0.492 \\
\hline Head ever traded & Discrete & 0.092 & 0.442 \\
\hline Head ever made handicrafts & Discrete & 0.021 & 0.151 \\
\hline A member cultivated last year & Discrete & 0.240 & 0.025 \\
\hline A member cultivated in the last 2 years & Discrete & 0.185 & 0.025 \\
\hline A member has never cultivated & Discrete & 0.034 & 0.025 \\
\hline A member traded last year & Discrete & 0.111 & 0.018 \\
\hline A member traded in the last 2 years & Discrete & 0.179 & 0.017 \\
\hline A member has never traded & Discrete & 0.629 & 0.011 \\
\hline A member herded last year & Discrete & 0.153 & 0.009 \\
\hline A member herded in the last 2 years & Discrete & 0.255 & 0.010 \\
\hline A member has never herded & Discrete & 0.380 & 0.012 \\
\hline A member made handicrafts last year & Discrete & 0.049 & 0.005 \\
\hline A member made handicrafts in the last 2 years & Discrete & 0.038 & 0.005 \\
\hline A member has never made handicrafts & Discrete & 0.801 & 0.009 \\
\hline IDP camp has markets & Discrete & 0.892 & 0.451 \\
\hline IDP camp has secondary school & Discrete & 0.429 & 0.477 \\
\hline IDP camp has primary school & Discrete & 0.897 & 0.451 \\
\hline IDP camp has health services & Discrete & 0.875 & 0.455 \\
\hline
\end{tabular}


Table 2. Summary statistics, IDP residents and returnee households

\begin{tabular}{|c|c|c|c|c|}
\hline \multirow[t]{2}{*}{ Variable } & \multicolumn{2}{|c|}{ Left the camp $(n=1,573)$} & \multicolumn{2}{|c|}{ Still in camp $(n=2,411$} \\
\hline & Mean & Std Dev & Mean & Std Dev \\
\hline Mean duration in IDP camp in years & 4.739 & 3.123 & 8.109 & 6.047 \\
\hline Member (15-64 years) died in the past 2 years & 0.004 & 0.087 & 0.019 & 0.123 \\
\hline Conflict intensity at location in 2006 & 2.658 & 2.646 & 5.090 & 4.670 \\
\hline Conflict intensity at origin in 2006 & 2.600 & 2.532 & 4.949 & 4.357 \\
\hline Age of household head & 41.89 & 14.537 & 42.69 & 15.677 \\
\hline Head is female & 0.199 & 0.387 & 0.287 & 0.433 \\
\hline Size of the household & 6.032 & 2.578 & 5.602 & 2.563 \\
\hline Ratio of males to females & 1.290 & 1.196 & 1.204 & 1.117 \\
\hline Head is single & 0.010 & 0.156 & 0.031 & 0.161 \\
\hline Head is married & 0.797 & 0.393 & 0.710 & 0.437 \\
\hline Head is widowed/divorced & 0.184 & 0.370 & 0.259 & 0.420 \\
\hline Head has no formal education & 0.296 & 0.367 & 0.403 & 0.489 \\
\hline Head has primary education & 0.527 & 0.500 & 0.443 & 0.499 \\
\hline Head has secondar eduction & 0.177 & 0.360 & 0.153 & 0.351 \\
\hline Proportion of the young (below 18) & 0.499 & 0.316 & 0.488 & 0.301 \\
\hline Head ever cultivated & 0.062 & 0.242 & 0.119 & 0.324 \\
\hline Head ever herded & 0.19 & 0.294 & 0.154 & 0.294 \\
\hline Head ever traded & 0.078 & 0.383 & 0.161 & 0.368 \\
\hline Head ever made handicrafts & 0.051 & 0.220 & 0.046 & 0.210 \\
\hline A member cultivated last year & 0.022 & 0.145 & 0.045 & 0.208 \\
\hline A member cultivated in the last 2 years & 0.017 & 0.130 & 0.040 & 0.196 \\
\hline A member has never cultivated & 0.027 & 0.161 & 0.039 & 0.193 \\
\hline A member traded last year & 0.129 & 0.335 & 0.109 & 0.312 \\
\hline A member traded in the last 2 years & 0.080 & 0.272 & 0.077 & 0.267 \\
\hline A member has never traded & 0.654 & 0.476 & 0.620 & 0.485 \\
\hline A member herded last year & 0.177 & 0.382 & 0.161 & 0.368 \\
\hline A member herded in the last 2 years & 0.245 & 0.430 & 0.276 & 0.447 \\
\hline A member has never herded & 0.355 & 0.479 & 0.404 & 0.491 \\
\hline A member made handicrafts last year & 0.049 & 0.216 & 0.048 & 0.213 \\
\hline A member made handicrafts in the last 2 years & 0.043 & 0.203 & 0.042 & 0.200 \\
\hline A member has never made handicrafts & 0.797 & 0.402 & 0.812 & 0.391 \\
\hline IDP camp has markets & 0.851 & 0.476 & 0.899 & 0.478 \\
\hline IDP camp has secondary school & 0.355 & 0.455 & 0.478 & 0.449 \\
\hline IDP camp has primary school & 0.821 & 0.451 & 0.865 & 0.457 \\
\hline IDP camp has health services & 0.794 & 0.485 & 0.812 & 0.484 \\
\hline
\end{tabular}


Table 3. Probit results for determinants of camp decongestion

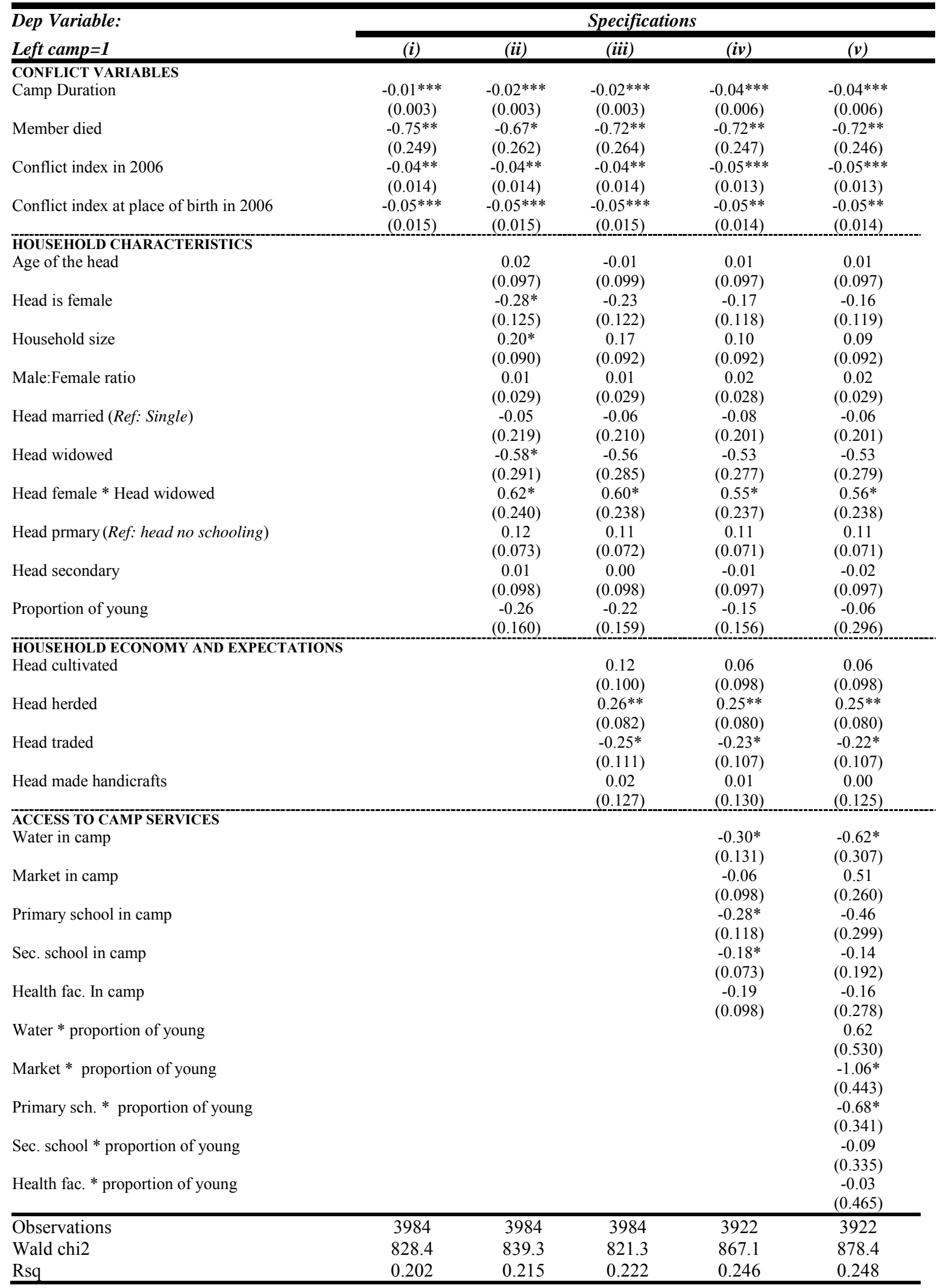

Notes: Robust standard errors in brackets. *Significant at $10 \%, * * 5 \%, * * * 1 \%$, District fixed effects included. 
Table 4. History of economic activities of the household

\begin{tabular}{|c|c|c|c|c|c|}
\hline \multirow{2}{*}{$\begin{array}{r}\text { Dep Var: } \\
\text { Returnee }\end{array}$} & \multicolumn{5}{|c|}{ Activity } \\
\hline & Cultivation & Trade & Herding & Handicrafts & All \\
\hline CULT_1YR (Ref: CULT_NEVER) & $\begin{array}{c}0.65^{*} \\
(0.266)\end{array}$ & & & & $\begin{array}{l}0.70 * * \\
(0.270)\end{array}$ \\
\hline CULT_2YR & $\begin{array}{c}0.20 * \\
(0.098)\end{array}$ & & & & $\begin{array}{c}0.22 * \\
(0.096)\end{array}$ \\
\hline TRADE_1YR (Ref: TRADE_NEVER) & & $\begin{array}{l}-0.25 * * \\
(0.086)\end{array}$ & & & $\begin{array}{l}-0.31 * * * \\
(0.089)\end{array}$ \\
\hline TRADE_2YR & & $\begin{array}{c}-0.05 * * * \\
(0.015)\end{array}$ & & & $\begin{array}{c}-0.02 \\
(0.096)\end{array}$ \\
\hline HERD_1YR (Ref: HERD_NEVER) & & & $\begin{array}{c}0.21 * \\
(0.088)\end{array}$ & & $\begin{array}{l}0.25 * * \\
(0.090)\end{array}$ \\
\hline HERD_2YR & & & $\begin{array}{c}-0.04 \\
(0.075)\end{array}$ & & $\begin{array}{c}-0.02 \\
(0.080)\end{array}$ \\
\hline CRAFT_1YR(Ref: CRAFT_NEVER) & & & & $\begin{array}{c}-0.01 \\
(0.135)\end{array}$ & $\begin{array}{c}-0.01 \\
(0.141)\end{array}$ \\
\hline CRAFT_2YR & & & & $\begin{array}{c}-0.04 \\
(0.148)\end{array}$ & $\begin{array}{c}-0.04 \\
(0.152)\end{array}$ \\
\hline DISTRICT FIXED EFFECTS & Yes & Yes & Yes & Yes & Yes \\
\hline Obs & 3922 & 3922 & 3922 & 3922 & 3922 \\
\hline Wald chi2 & 880.8 & 841.9 & 834.0 & 838.6 & 878.3 \\
\hline Rsq & 0.217 & 0.219 & 0.218 & 0.216 & 0.226 \\
\hline
\end{tabular}

Notes: Robust standard errors in brackets. ${ }^{*}$ Significant at $10 \%, * *$ Significant at $5 \%$, ***Significant at $1 \%$. Other variables in specification 4 included, except for participation of the head in economic activities. CULT_1YR, TRADE_1YR, HERD_1YR, CRAFT_1YR are dummies representing any member of the household who cultivated, traded, herded and made handicrafts in the past one year respectively; CULT_2YR, TRADE_2YR, HERD_2YR, CRAFT_2YR; for members who cultivated, traded, herded and made handicrafts in the past two years respectively; CULT_NEVER, TRADE_NEVER, HERD_NEVER, CRAFT_NEVER, for a member who never engaged in the respective activities. 
Table 5. History of economic activities of the household (Acholi sub region)

\begin{tabular}{|c|c|c|c|c|c|c|c|c|c|c|}
\hline \multirow{2}{*}{$\begin{array}{l}\text { Dep Var: } \\
\text { Returnee }\end{array}$} & \multicolumn{5}{|c|}{ Acholi Sub region } & \multicolumn{5}{|c|}{ Lango Sub region } \\
\hline & Cultivation & Trade & Herding & Crafts & All & Cultivation & Trade & Herding & Crafts & All \\
\hline CULT_1YR (Ref: CULT_NEVER) & $\begin{array}{c}0.57^{*} \\
(0.253)\end{array}$ & & & & $\begin{array}{l}0.69^{* *} \\
(0.260)\end{array}$ & $\begin{array}{c}0.11^{*} \\
(0.050)\end{array}$ & & & & $\begin{array}{c}0.12 * \\
(0.051)\end{array}$ \\
\hline CULT_2YR & $\begin{array}{c}0.31 \\
(0.277)\end{array}$ & & & & $\begin{array}{c}0.37 \\
(0.276)\end{array}$ & $\begin{array}{c}0.55 \\
(0.536)\end{array}$ & & & & $\begin{array}{c}0.67 \\
(0.564)\end{array}$ \\
\hline TRADE_1YR(Ref: TRADE_NEVER) & & $\begin{array}{c}-0.27 * * \\
(0.102)\end{array}$ & & & $\begin{array}{c}-0.29 * * \\
(0.107)\end{array}$ & & $\begin{array}{l}-0.38^{*} \\
(0.152)\end{array}$ & & & $\begin{array}{l}-0.38^{*} \\
(0.160)\end{array}$ \\
\hline TRADE_2YR & & $\begin{array}{c}-0.10 \\
(0.102)\end{array}$ & & & $\begin{array}{c}-0.08 \\
(0.107)\end{array}$ & & $\begin{array}{l}-0.15^{*} \\
(0.074)\end{array}$ & & & $\begin{array}{l}-0.16^{*} \\
(0.074)\end{array}$ \\
\hline HERD_1YR (Ref: HERD_NEVER) & & & $\begin{array}{c}0.21 * \\
(0.099)\end{array}$ & & $\begin{array}{c}0.20 \\
(0.109)\end{array}$ & & & $\begin{array}{c}0.31 * \\
(0.142)\end{array}$ & & $\begin{array}{c}0.36^{*} \\
(0.144)\end{array}$ \\
\hline HERD_2YR & & & $\begin{array}{c}0.11 \\
(0.095)\end{array}$ & & $\begin{array}{c}0.15 \\
(0.101)\end{array}$ & & & $\begin{array}{c}0.21 \\
(0.169)\end{array}$ & & $\begin{array}{c}0.33 \\
(0.169)\end{array}$ \\
\hline CRAFT_1YR(Ref: CRAFT_NEVER) & & & & $\begin{array}{c}0.16 \\
(0.112)\end{array}$ & $\begin{array}{c}0.13 \\
(0.117)\end{array}$ & & & & $\begin{array}{c}0.25 \\
(0.172)\end{array}$ & $\begin{array}{c}0.31 \\
(0.181)\end{array}$ \\
\hline CRAFT_2YR & & & & $\begin{array}{c}-0.11 \\
(0.143)\end{array}$ & $\begin{array}{c}-0.14 \\
(0.148)\end{array}$ & & & & $\begin{array}{c}-0.18 \\
(0.229)\end{array}$ & $\begin{array}{c}-0.18 \\
(0.239)\end{array}$ \\
\hline Observations & 2523 & 2523 & 2523 & 2523 & 2523 & 1399 & 1399 & 1399 & 1399 & 1399 \\
\hline Wald chi2 & 120.0 & 121.4 & 117.0 & 118.3 & 137.2 & 40.86 & 49.00 & 44.34 & 40.02 & 59.78 \\
\hline Rsq & 0.0630 & 0.0651 & 0.0611 & 0.0609 & 0.0725 & 0.0423 & 0.0484 & 0.0492 & 0.0440 & 0.0683 \\
\hline
\end{tabular}

Notes: Robust standard errors in brackets. ${ }^{*}$ Significant at $10 \%, * *$ Significant at $5 \%$, ***Significant at $1 \%$. Other variables in specification 4 included, except for participation of the head in economic activities. CULT_1YR, TRADE_1YR, HERD_1YR, CRAFT_1YR are dummies representing any member of the household who cultivated, traded, herded and made handicrafts in the past one year respectively; CULT_2YR, TRADE_2YR, HERD_2YR, CRAFT_2YR, for members who cultivated, traded, herded and made handicrafts in the past two years respectively; CULT_NEVER, TRADE_NEVER, HERD_NEVER, CRAFT_NEVER, for a member who never engaged in the respective activities. 
Table 6. Probit results for Acholi and Lango sub regions

\begin{tabular}{|c|c|c|c|c|c|c|c|c|c|c|}
\hline \multirow{2}{*}{$\begin{array}{l}\text { Dep Variable: } \\
\text { Left camp }\end{array}$} & \multicolumn{5}{|c|}{ Acholi Sub region } & \multicolumn{5}{|c|}{ Lango sub region } \\
\hline & (i) & (ii) & (iii) & (iv) & $(v)$ & (i) & (ii) & (iii) & (iv) & $(v)$ \\
\hline \multicolumn{11}{|l|}{ CONFLICT VARIABLES } \\
\hline Camp Duration & $\begin{array}{c}-0.01 * * * \\
(0.004)\end{array}$ & $\begin{array}{c}-0.02 * * * \\
(0.004)\end{array}$ & $\begin{array}{c}-0.02 * * * \\
(0.004)\end{array}$ & $\begin{array}{c}-0.05 * * * \\
(0.007)\end{array}$ & $\begin{array}{c}-0.05 * * * \\
(0.007)\end{array}$ & $\begin{array}{l}-0.02 * * \\
(0.005)\end{array}$ & $\begin{array}{c}-0.02 * * * \\
(0.006)\end{array}$ & $\begin{array}{c}-0.02 * * * \\
(0.006)\end{array}$ & $\begin{array}{c}-0.05 * * * \\
(0.012)\end{array}$ & $\begin{array}{c}-0.05^{* * *} \\
(0.012)\end{array}$ \\
\hline Member died & $\begin{array}{c}-0.86^{* * *} \\
(0.219)\end{array}$ & $\begin{array}{l}-0.76^{* *} \\
(0.231)\end{array}$ & $\begin{array}{c}-0.79 * * * \\
(0.232)\end{array}$ & $\begin{array}{c}-0.74 * * \\
(0.234)\end{array}$ & $\begin{array}{l}-0.75^{* *} \\
(0.233)\end{array}$ & $\begin{array}{c}-0.44 \\
(0.552)\end{array}$ & $\begin{array}{c}-0.40 \\
(0.552)\end{array}$ & $\begin{array}{c}-0.49 \\
(0.516)\end{array}$ & $\begin{array}{c}-0.65 \\
(0.469)\end{array}$ & $\begin{array}{c}-0.64 \\
(0.470)\end{array}$ \\
\hline Index in 2006 & $\begin{array}{c}-0.02 \\
(0.015)\end{array}$ & $\begin{array}{c}-0.02 \\
(0.015)\end{array}$ & $\begin{array}{c}-0.02 \\
(0.015)\end{array}$ & $\begin{array}{c}-0.02 \\
(0.014)\end{array}$ & $\begin{array}{c}-0.02 \\
(0.014)\end{array}$ & $\begin{array}{c}-0.05 \\
(0.046)\end{array}$ & $\begin{array}{l}-0.06 \\
(0.046)\end{array}$ & $\begin{array}{c}-0.06 \\
(0.045)\end{array}$ & $\begin{array}{c}-0.07 \\
(0.048)\end{array}$ & $\begin{array}{c}-0.08 \\
(0.048)\end{array}$ \\
\hline Ind at place of birth in 06 & $\begin{array}{c}-0.04 * * \\
(0.016)\end{array}$ & $\begin{array}{l}-0.04^{* *} \\
(0.016)\end{array}$ & $\begin{array}{c}-0.04^{* *} \\
(0.016)\end{array}$ & $\begin{array}{l}-0.04 * * \\
(0.015)\end{array}$ & $\begin{array}{l}-0.04 * * \\
(0.015)\end{array}$ & $\begin{array}{l}-0.11^{*} \\
(0.051)\end{array}$ & $\begin{array}{l}-0.11 * \\
(0.051)\end{array}$ & $\begin{array}{l}-0.12 * \\
(0.049)\end{array}$ & $\begin{array}{l}-0.12 * \\
(0.051)\end{array}$ & $\begin{array}{l}-0.12 * \\
(0.051)\end{array}$ \\
\hline \multicolumn{11}{|c|}{ HOUSEHOLD CHARACTERISTICS } \\
\hline \multicolumn{2}{|c|}{ Age of the head } & $\begin{array}{c}0.13 \\
(0.108)\end{array}$ & $\begin{array}{c}0.14 \\
(0.111)\end{array}$ & $\begin{array}{c}0.14 \\
(0.112)\end{array}$ & $\begin{array}{c}0.15 \\
(0.112)\end{array}$ & & $\begin{array}{c}0.03 \\
(0.158)\end{array}$ & $\begin{array}{c}-0.01 \\
(0.162)\end{array}$ & $\begin{array}{l}-0.00 \\
(0.153)\end{array}$ & $\begin{array}{c}0.01 \\
(0.154)\end{array}$ \\
\hline \multicolumn{2}{|l|}{ Head is female } & $\begin{array}{c}-0.56^{* * *} \\
(0.140)\end{array}$ & $\begin{array}{c}-0.55^{* * *} \\
(0.141)\end{array}$ & $\begin{array}{c}-0.47^{* * *} \\
(0.138)\end{array}$ & $\begin{array}{c}-0.47 * * * \\
(0.138)\end{array}$ & & $\begin{array}{c}0.14 \\
(0.304)\end{array}$ & $\begin{array}{c}0.26 \\
(0.270)\end{array}$ & $\begin{array}{c}0.28 \\
(0.235)\end{array}$ & $\begin{array}{c}0.29 \\
(0.242)\end{array}$ \\
\hline \multicolumn{2}{|l|}{ Household size } & $\begin{array}{c}0.18 \\
(0.096)\end{array}$ & $\begin{array}{c}0.16 \\
(0.098)\end{array}$ & $\begin{array}{c}0.09 \\
(0.098)\end{array}$ & $\begin{array}{c}0.09 \\
(0.097)\end{array}$ & & $\begin{array}{c}0.25 \\
(0.141)\end{array}$ & $\begin{array}{c}0.17 \\
(0.144)\end{array}$ & $\begin{array}{c}0.03 \\
(0.143)\end{array}$ & $\begin{array}{c}0.01 \\
(0.145)\end{array}$ \\
\hline \multicolumn{2}{|l|}{ Male:Female ratio } & $\begin{array}{c}0.03 \\
(0.031)\end{array}$ & $\begin{array}{c}0.03 \\
(0.031)\end{array}$ & $\begin{array}{c}0.04 \\
(0.033)\end{array}$ & $\begin{array}{c}0.04 \\
(0.032)\end{array}$ & & $\begin{array}{c}-0.04 \\
(0.046)\end{array}$ & $\begin{array}{c}-0.03 \\
(0.047)\end{array}$ & $\begin{array}{c}-0.01 \\
(0.044)\end{array}$ & $\begin{array}{c}-0.01 \\
(0.045)\end{array}$ \\
\hline \multicolumn{2}{|l|}{ Head married (Ref: Single) } & $\begin{array}{c}0.00 \\
(0.202)\end{array}$ & $\begin{array}{c}-0.03 \\
(0.204)\end{array}$ & $\begin{array}{l}-0.00 \\
(0.201)\end{array}$ & $\begin{array}{l}-0.01 \\
(0.204)\end{array}$ & & $\begin{array}{l}-0.22 \\
\quad(0.557)\end{array}$ & $\begin{array}{l}-0.25 \\
\quad(0.499)\end{array}$ & $\begin{array}{l}-0.39 \\
\quad(0.452)\end{array}$ & $\begin{array}{l}-0.36 \\
\quad(0.424)\end{array}$ \\
\hline \multicolumn{2}{|l|}{ Head widowed } & $\begin{array}{c}-0.24 \\
(0.294)\end{array}$ & $\begin{array}{c}-0.24 \\
(0.299)\end{array}$ & $\begin{array}{c}-0.12 \\
(0.290)\end{array}$ & $\begin{array}{c}-0.13 \\
(0.295)\end{array}$ & & $\begin{array}{c}-1.02 \\
(0.630)\end{array}$ & $\begin{array}{c}-1.02 \\
(0.577)\end{array}$ & $\begin{array}{c}-1.25^{*} \\
(0.529)\end{array}$ & $\begin{array}{c}-1.26^{*} \\
(0.514)\end{array}$ \\
\hline \multicolumn{2}{|c|}{ Head female $*$ Head widowed } & $\begin{array}{c}-0.58 * * * \\
(0.159)\end{array}$ & $\begin{array}{c}-0.57 * * * \\
(0.160)\end{array}$ & $\begin{array}{l}-0.50 * * \\
(0.156)\end{array}$ & $\begin{array}{l}-0.49 * * \\
(0.156)\end{array}$ & & $\begin{array}{c}0.56 \\
(0.422)\end{array}$ & $\begin{array}{c}0.50 \\
(0.403)\end{array}$ & $\begin{array}{c}0.57 \\
(0.377)\end{array}$ & $\begin{array}{c}0.62 \\
(0.384)\end{array}$ \\
\hline \multicolumn{2}{|c|}{ Head prmary (Ref: head no schooling) } & $\begin{array}{c}-0.03 \\
(0.078)\end{array}$ & $\begin{array}{c}-0.04 \\
(0.078)\end{array}$ & $\begin{array}{c}-0.03 \\
(0.078)\end{array}$ & $\begin{array}{l}-0.03 \\
(0.079)\end{array}$ & & $\begin{array}{l}0.21 \\
(0.136)\end{array}$ & $\begin{array}{l}0.19 \\
\quad(0.135)\end{array}$ & $\begin{array}{l}0.17 \\
(0.127)\end{array}$ & $\begin{array}{l}0.19 \\
(0.128)\end{array}$ \\
\hline \multicolumn{2}{|l|}{ Head secondary } & $\begin{array}{c}-0.20 \\
(0.116)\end{array}$ & $\begin{array}{c}-0.20 \\
(0.117)\end{array}$ & $\begin{array}{l}-0.23^{*} \\
(0.115)\end{array}$ & $\begin{array}{c}-0.22 \\
(0.115)\end{array}$ & & $\begin{array}{c}0.22 \\
(0.170)\end{array}$ & $\begin{array}{c}0.19 \\
(0.169)\end{array}$ & $\begin{array}{c}0.17 \\
(0.165)\end{array}$ & $\begin{array}{c}0.17 \\
(0.166)\end{array}$ \\
\hline \multicolumn{2}{|l|}{ Proportion of young } & $\begin{array}{c}-0.04 \\
(0.175) \\
\end{array}$ & $\begin{array}{c}-0.01 \\
(0.177) \\
\end{array}$ & $\begin{array}{c}0.10 \\
(0.177) \\
\end{array}$ & $\begin{array}{c}0.09 \\
(0.357) \\
\end{array}$ & & $\begin{array}{c}-0.32 \\
(0.246) \\
\end{array}$ & $\begin{array}{c}-0.21 \\
(0.245) \\
\end{array}$ & $\begin{array}{c}-0.13 \\
(0.235) \\
\end{array}$ & $\begin{array}{c}0.19 \\
(0.488) \\
\end{array}$ \\
\hline \multicolumn{11}{|l|}{ HOUSEHOLD ECONOMY } \\
\hline Head cultivated & & & $\begin{array}{c}0.19 \\
(0.101)\end{array}$ & $\begin{array}{c}0.16 \\
(0.100)\end{array}$ & $\begin{array}{c}0.15 \\
(0.100)\end{array}$ & & & $\begin{array}{c}0.21 \\
(0.177)\end{array}$ & $\begin{array}{c}0.07 \\
(0.174)\end{array}$ & $\begin{array}{c}0.06 \\
(0.172)\end{array}$ \\
\hline Head herded & & & $\begin{array}{c}0.02 \\
(0.102)\end{array}$ & $\begin{array}{c}0.03 \\
(0.100)\end{array}$ & $\begin{array}{c}0.02 \\
(0.101)\end{array}$ & & & $\begin{array}{l}0.42 * * \\
(0.132)\end{array}$ & $\begin{array}{l}0.39^{* *} \\
(0.126)\end{array}$ & $\begin{array}{l}0.40^{* *} \\
(0.126)\end{array}$ \\
\hline Head traded & & & $\begin{array}{l}-0.23^{*} \\
(0.101)\end{array}$ & $\begin{array}{l}-0.21 * \\
(0.101)\end{array}$ & $\begin{array}{c}-0.13 \\
(0.104)\end{array}$ & & & $\begin{array}{l}-0.26^{*} \\
(0.128)\end{array}$ & $\begin{array}{l}-0.26^{*} \\
(0.128)\end{array}$ & $\begin{array}{l}-0.30^{*} \\
(0.127)\end{array}$ \\
\hline Head made handicrafts & & & $\begin{array}{c}0.22 \\
(0.179) \\
\end{array}$ & $\begin{array}{c}0.18 \\
(0.178) \\
\end{array}$ & $\begin{array}{c}0.18 \\
(0.179) \\
\end{array}$ & & & $\begin{array}{c}0.21 \\
(0.222) \\
\end{array}$ & $\begin{array}{c}0.09 \\
(0.200) \\
\end{array}$ & $\begin{array}{c}0.10 \\
(0.201)\end{array}$ \\
\hline \multicolumn{11}{|l|}{ ACCESS TO FACILITIES } \\
\hline Water in camp & & & & $\begin{array}{c}-0.16 \\
(0.186)\end{array}$ & $\begin{array}{c}-0.73 \\
(0.492)\end{array}$ & & & & $\begin{array}{c}-0.35 \\
(0.205)\end{array}$ & $\begin{array}{c}-0.46 \\
(0.443)\end{array}$ \\
\hline Market in camp & & & & $\begin{array}{l}-0.27 \\
(0.143)\end{array}$ & $\begin{array}{c}0.66 \\
(0.407)\end{array}$ & & & & $\begin{array}{c}0.07 \\
(0.147)\end{array}$ & $\begin{array}{c}0.49 \\
(0.382)\end{array}$ \\
\hline Primary school in camp & & & & $\begin{array}{l}-0.41^{*} \\
(0.161)\end{array}$ & $\begin{array}{c}-0.65 \\
(0.430)\end{array}$ & & & & $\begin{array}{l}-0.52^{*} \\
(0.211)\end{array}$ & $\begin{array}{c}-0.78 \\
(0.488)\end{array}$ \\
\hline Sec. school in camp & & & & $\begin{array}{l}-0.08 \\
(0.080)\end{array}$ & $\begin{array}{c}-0.22 \\
(0.223)\end{array}$ & & & & $\begin{array}{c}-0.45^{* * * *} \\
(0.120)\end{array}$ & $\begin{array}{c}-0.31 \\
(0.290)\end{array}$ \\
\hline Health fac. In camp & & & & $\begin{array}{c}-0.17 \\
(0.136)\end{array}$ & $\begin{array}{c}-0.18 \\
(0.374)\end{array}$ & & & & $\begin{array}{c}-0.05 \\
(0.144)\end{array}$ & $\begin{array}{c}0.14 \\
(0.351)\end{array}$ \\
\hline Water * proportion of you & & & & & $\begin{array}{c}1.07 \\
(0.853)\end{array}$ & & & & & $\begin{array}{c}0.22 \\
(0.727)\end{array}$ \\
\hline Market $*$ proportion of yc & & & & & $\begin{array}{l}-1.77^{*} \\
(0.697)\end{array}$ & & & & & $\begin{array}{c}-0.79 \\
(0.626)\end{array}$ \\
\hline Primary sch. * proportion of & & & & & $\begin{array}{c}0.42 \\
(0.756)\end{array}$ & & & & & $\begin{array}{c}0.48 \\
(0.778)\end{array}$ \\
\hline Sec. school $*$ proportion o & ung & & & & $\begin{array}{c}0.25 \\
(0.377)\end{array}$ & & & & & $\begin{array}{c}-0.26 \\
(0.500)\end{array}$ \\
\hline Health fac. $*$ proportion $\mathrm{o}$ & ung & & & & 0.12 & & & & & $\begin{array}{c}-0.36 \\
(0.581)\end{array}$ \\
\hline Observations & 2573 & 2523 & 2523 & 2523 & 2523 & 1411 & 1399 & 1399 & 1399 & 1399 \\
\hline Wald chi2 & 72.57 & 114.1 & 118.1 & 176.6 & 184.9 & 13.51 & 38.71 & 50.96 & 114.2 & 117.0 \\
\hline Rsq & 0.0393 & 0.0596 & 0.0629 & 0.0940 & 0.0965 & 0.0144 & 0.0404 & 0.0597 & 0.111 & 0.115 \\
\hline
\end{tabular}

Notes: Robust standard errors in brackets. *Significant at $10 \%, * * 5 \%, * * * 1 \%$, District fixed effects included. 
Table 7. Excluding commuting households

\begin{tabular}{|c|c|c|c|c|c|}
\hline \multirow{2}{*}{$\begin{array}{l}\text { Dep Variable: } \\
\text { Left camp }=1\end{array}$} & \multicolumn{5}{|c|}{ Specifications } \\
\hline & (i) & (ii) & (iii) & (iv) & $(v)$ \\
\hline \multicolumn{6}{|l|}{ CONFLICT VARIABLES } \\
\hline Camp Duration & $\begin{array}{c}-0.01 * * * \\
(0.004)\end{array}$ & $\begin{array}{c}-0.02 * * * \\
(0.004)\end{array}$ & $\begin{array}{c}-0.02 * * * \\
(0.004)\end{array}$ & $\begin{array}{c}-0.04 * * * \\
(0.007)\end{array}$ & $\begin{array}{c}-0.04 * * * \\
(0.007)\end{array}$ \\
\hline Member died & $\begin{array}{c}-0.66^{* *} \\
(0.258)\end{array}$ & $\begin{array}{l}-0.60^{*} \\
(0.269)\end{array}$ & $\begin{array}{l}-0.65^{*} \\
(0.269)\end{array}$ & $\begin{array}{c}-0.66 * * \\
(0.253)\end{array}$ & $\begin{array}{c}-0.65 * * \\
(0.251)\end{array}$ \\
\hline Index in 2006 & $\begin{array}{c}-0.05 * * * \\
(0.013)\end{array}$ & $\begin{array}{c}-0.05 * * * \\
(0.014)\end{array}$ & $\begin{array}{c}-0.05 * * * \\
(0.014)\end{array}$ & $\begin{array}{c}-0.05 * * * \\
(0.013)\end{array}$ & $\begin{array}{c}-0.05 * * * \\
(0.013)\end{array}$ \\
\hline Index at place of birth in 2006 & $\begin{array}{r}-0.04 * * \\
(0.014) \\
\end{array}$ & $\begin{array}{l}-0.04 * * \\
(0.015) \\
\end{array}$ & $\begin{array}{r}-0.04^{* *} \\
(0.015) \\
\end{array}$ & $\begin{array}{r}-0.04 * * \\
(0.015) \\
\end{array}$ & $\begin{array}{l}-0.04 * * \\
(0.015)\end{array}$ \\
\hline \multicolumn{6}{|l|}{ HOUSEHOLD CHARACTERISTICS } \\
\hline Age of the head & & $\begin{array}{c}-0.01 \\
(0.103)\end{array}$ & $\begin{array}{c}-0.04 \\
(0.105)\end{array}$ & $\begin{array}{c}-0.01 \\
(0.103)\end{array}$ & $\begin{array}{c}-0.01 \\
(0.103)\end{array}$ \\
\hline Head is female & & $\begin{array}{l}-0.30^{*} \\
(0.135)\end{array}$ & $\begin{array}{l}-0.25 \\
(0.132)\end{array}$ & $\begin{array}{l}-0.20 \\
(0.128)\end{array}$ & $\begin{array}{c}-0.19 \\
(0.128)\end{array}$ \\
\hline Household size & & $\begin{array}{c}0.23^{*} \\
(0.096)\end{array}$ & $\begin{array}{c}0.19^{*} \\
(0.097)\end{array}$ & $\begin{array}{c}0.11 \\
(0.097)\end{array}$ & $\begin{array}{c}0.10 \\
(0.098)\end{array}$ \\
\hline Male:Female ratio & & $\begin{array}{c}0.00 \\
(0.031)\end{array}$ & $\begin{array}{c}0.00 \\
(0.031)\end{array}$ & $\begin{array}{c}0.02 \\
(0.030)\end{array}$ & $\begin{array}{c}0.02 \\
(0.030)\end{array}$ \\
\hline Head married (Ref: Single) & & $\begin{array}{c}0.03 \\
(0.245)\end{array}$ & $\begin{array}{c}0.03 \\
(0.234)\end{array}$ & $\begin{array}{c}0.01 \\
(0.225)\end{array}$ & $\begin{array}{c}0.03 \\
(0.226)\end{array}$ \\
\hline Head widowed & & $\begin{array}{c}-0.43 \\
(0.317)\end{array}$ & $\begin{array}{l}-0.40 \\
(0.309)\end{array}$ & $\begin{array}{c}-0.39 \\
(0.301)\end{array}$ & $\begin{array}{c}-0.38 \\
(0.305)\end{array}$ \\
\hline Head female $*$ Head widowed & & $\begin{array}{c}0.65^{*} \\
(0.253)\end{array}$ & $\begin{array}{c}0.62 * \\
(0.251)\end{array}$ & $\begin{array}{c}0.58^{*} \\
(0.250)\end{array}$ & $\begin{array}{c}0.59^{*} \\
(0.252)\end{array}$ \\
\hline Head prmary (Ref: head no schooling) & & $\begin{array}{c}0.11 \\
(0.078)\end{array}$ & $\begin{array}{c}0.10 \\
(0.078)\end{array}$ & $\begin{array}{c}0.10 \\
(0.076)\end{array}$ & $\begin{array}{c}0.10 \\
(0.076)\end{array}$ \\
\hline Head secondary & & $\begin{array}{c}0.00 \\
(0.104)\end{array}$ & $\begin{array}{l}-0.01 \\
(0.105)\end{array}$ & $\begin{array}{c}-0.03 \\
(0.103)\end{array}$ & $\begin{array}{c}-0.03 \\
(0.103)\end{array}$ \\
\hline Proportion of young & & $\begin{array}{c}-0.32 \\
(0.170) \\
\end{array}$ & $\begin{array}{c}-0.28 \\
(0.168) \\
\end{array}$ & $\begin{array}{c}-0.21 \\
(0.166) \\
\end{array}$ & $\begin{array}{c}-0.01 \\
(0.319) \\
\end{array}$ \\
\hline \multicolumn{6}{|l|}{ HOUSEHOLD ECONOMY } \\
\hline Head cultivated & & & $\begin{array}{c}0.10 \\
(0.107)\end{array}$ & $\begin{array}{c}0.03 \\
(0.105)\end{array}$ & $\begin{array}{c}0.02 \\
(0.105)\end{array}$ \\
\hline Head herded & & & $\begin{array}{l}0.27 * * \\
(0.086)\end{array}$ & $\begin{array}{l}0.26^{* *} \\
(0.084)\end{array}$ & $\begin{array}{l}0.25^{* *} \\
(0.083)\end{array}$ \\
\hline Head traded & & & $\begin{array}{c}0.03 \\
(0.139) \\
\end{array}$ & $\begin{array}{c}-0.00 \\
(0.131) \\
\end{array}$ & $\begin{array}{l}-0.00 \\
(0.131)\end{array}$ \\
\hline \multicolumn{6}{|l|}{ ACCESS TO CAMP SERVICES } \\
\hline Water in camp & & & & $\begin{array}{l}-0.29 * \\
(0.138)\end{array}$ & $\begin{array}{c}-0.55 \\
(0.312)\end{array}$ \\
\hline Market in camp & & & & $\begin{array}{l}-0.05 \\
(0.103)\end{array}$ & $\begin{array}{c}0.51 \\
(0.265)\end{array}$ \\
\hline Primary school in camp & & & & $\begin{array}{l}-0.30^{*} \\
(0.125)\end{array}$ & $\begin{array}{l}-0.46 \\
(0.303)\end{array}$ \\
\hline Sec. school in camp & & & & $\begin{array}{l}-0.18^{*} \\
(0.077)\end{array}$ & $\begin{array}{l}-0.14 \\
(0.203)\end{array}$ \\
\hline Health fac. In camp & & & & $\begin{array}{l}-0.20^{*} \\
(0.102)\end{array}$ & $\begin{array}{c}-0.18 \\
(0.278)\end{array}$ \\
\hline Water * proportion of young & & & & & $\begin{array}{c}0.50 \\
(0.541)\end{array}$ \\
\hline Market * proportion of young & & & & & $\begin{array}{l}-1.06^{*} \\
(0.455)\end{array}$ \\
\hline Primary sch. * proportion of young & & & & & $\begin{array}{c}0.28 \\
(0.529)\end{array}$ \\
\hline Sec. school * proportion of young & & & & & $\begin{array}{c}-0.08 \\
(0.353)\end{array}$ \\
\hline Health fac. $*$ proportion of young & & & & & $\begin{array}{c}-0.02 \\
(0.467)\end{array}$ \\
\hline DISTRICT FIXED EFFECTS & YES & YES & YES & YES & YES \\
\hline $\begin{array}{ll}\text { Wald chi2 } & \text { Observations } \\
\text { Rsq } & \end{array}$ & $\begin{array}{l}3708 \\
783.8 \\
0.224\end{array}$ & $\begin{array}{l}3708 \\
771.3 \\
0.226\end{array}$ & $\begin{array}{l}3708 \\
747.6 \\
0.246\end{array}$ & $\begin{array}{l}3649 \\
804.3 \\
0.254\end{array}$ & $\begin{array}{l}3649 \\
833.0 \\
0.268\end{array}$ \\
\hline
\end{tabular}

Notes: Robust standard errors in brackets. *Significant at $10 \%,{ }^{*}$ Significant at $5 \%, * * *$ Significant at $1 \%$ 
Table 8. Multinomial logit results (base category: camp resident)

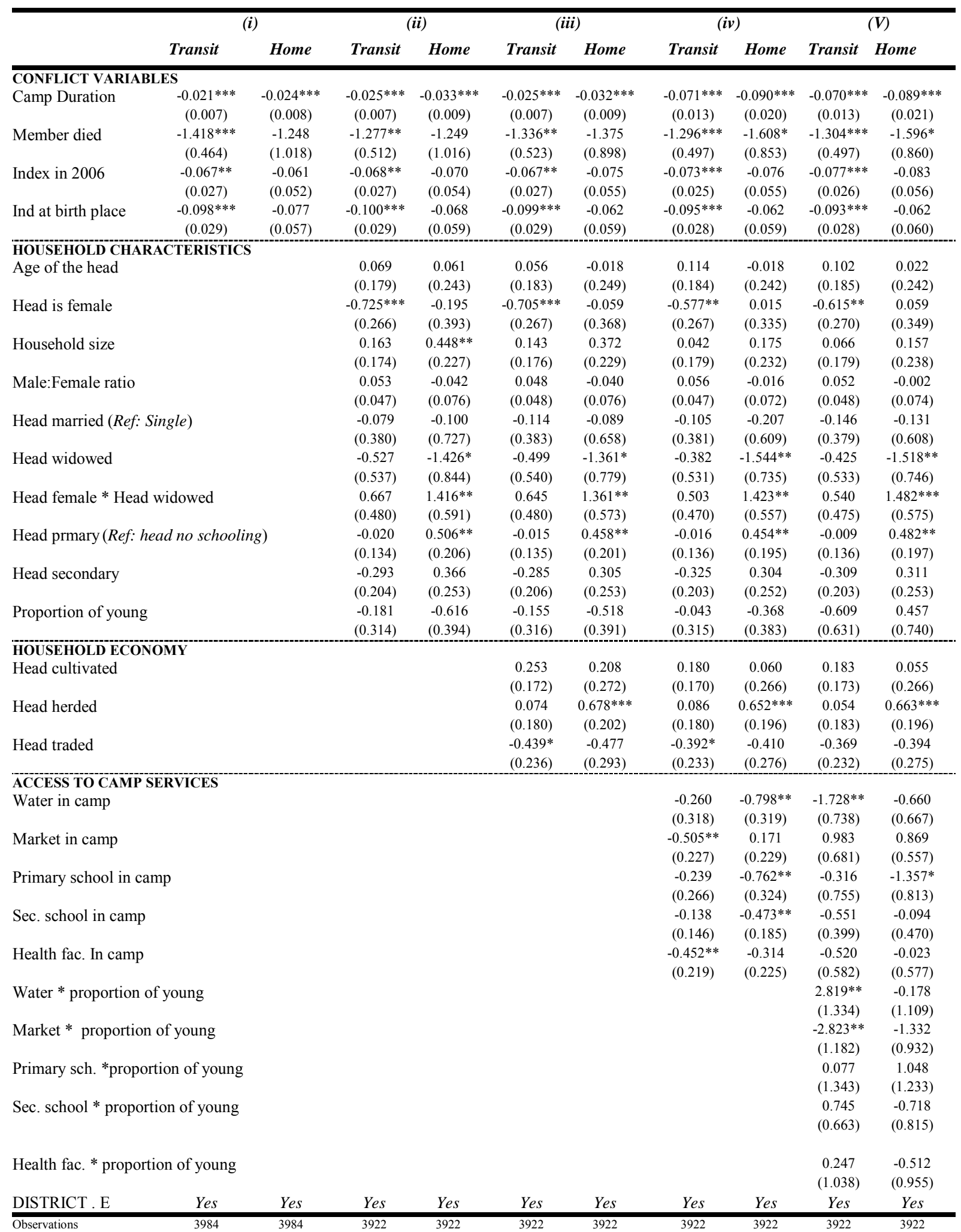

Notes: Robust standard errors in brackets. *Significant at 10\%, **Significant at 5\%, ***Significant at $1 \%$ 
Table 9. Effect of external events

\begin{tabular}{|c|c|c|c|c|}
\hline & (i) & (ii) & (iii) & (iv) \\
\hline \multicolumn{5}{|l|}{ Only locations in the survey } \\
\hline Index in 2006 & $\begin{array}{c}-0.04 * * \\
(0.014)\end{array}$ & & & \\
\hline Index at place of birth in 2006 & $\begin{array}{c}-0.05 * * * \\
(0.015)\end{array}$ & & & \\
\hline \multicolumn{5}{|l|}{ Other locations in Uganda } \\
\hline Index in 2006 & & $\begin{array}{c}6.63 \\
(5.919)\end{array}$ & & \\
\hline Index at place of birth in 2006 & & $\begin{array}{c}-0.02 \\
(0.015)\end{array}$ & & \\
\hline \multicolumn{5}{|l|}{ Only other countries (DRC, CAR, Sudan) } \\
\hline Index in 2006 & & & $\begin{array}{c}1.72 \\
(4.598)\end{array}$ & \\
\hline Index at place of birth in 2006 & & & $\begin{array}{c}-0.16 \\
(0.329)\end{array}$ & \\
\hline \multicolumn{5}{|l|}{ All locations } \\
\hline Index in 2006 & & & & $\begin{array}{c}-0.02 * * * \\
(0.005)\end{array}$ \\
\hline Index at place of birth in 2006 & & & & $-0.02 * *$ \\
\hline Observations & 3984 & 3838 & 3838 & 3913 \\
\hline Wald chi2 & 828.4 & 738.4 & 745.1 & 731.1 \\
\hline Rsq & 0.202 & 0.178 & 0.176 & 0.195 \\
\hline
\end{tabular}

Notes: Robust standard errors in brackets. ${ }^{*}$ Significant at $10 \%, * *$ Significant at $5 \%,{ }^{* * *}$ Significant at $1 \%$ 